\title{
Thomas Craig on the origin and development of feudal law
}

Leslie Dodd

Edinburgh Napier University

L.Dodd@,napier.ac.uk

This is an Accepted Manuscript of an article published by Brill in

Tijdscrhift voor Rechtsgeschiedenis 87 (2019) 86-127

DOI 10.1163/15718190-08712P04

It can be found online at:

\section{https://brill.com/abstract/journals/lega/87/1-2/article-p86 4.xml}

\begin{abstract}
Summary
When Thomas Craig (c.1538-1608) wrote his great treatise on Scottish feudal practice, the Jus feudale, he devoted a considerable part of the first book to legal origins. This article deals with Craig's treatment narrative on the origins of feudal law and tenure in the fourth and fifth titles of the first book. By close examination of the text, the detailed formulation of Craig's argumentation and technique is uncovered as well as the myriad classical, mediaeval and humanist sources upon which his literary project was based. In this way, the deep relationship between Craig - and by extension Scots law - and the historico-legal product of the French legal humanists is explored.
\end{abstract}

\section{Keywords}

Thomas Craig - feudal law - Scotland - Scottish legal history - Jus feudale - Tacitus - legal humanism - feudalism

\section{Introduction}


A fascination with origins is one of the features distinguishing the humanists of the Renaissance from their mediaeval predecessors. When jurists in the early sixteenth century first began to apply humanist methodologies to the study of law, they imported this characteristic to their own sphere; but for lawyers in particular the impetus to excavate the true origins and sources of law was innate to their profession. ${ }^{1}$ Within any system or structure that derives its authority from precedent, origins matter. The purpose of this article is to examine the account of the origins of feudal law and tenure given by the Scottish jurist Thomas Craig in the Jus feudale. By examining the intersection of feudal legal theory and humanist historical technique in the Jus feudale, we will arrive at a better understanding how Craig's work relates to the larger body of European legal humanist and feudal legal literature.

The historiographical approach taken by the legal humanists was relatively intuitive. They construed contemporary juristic structures as linked with the original context or circumstances in which the earliest form of those structures had emerged. Law, as they saw it, had a point of origin at which it had come into existence and from that point it evolved and developed over time adding new elements and adapting existing ones; the ways in which law and legal structures had evolved were informative for their interpretation and application of the contemporary structure. ${ }^{2}$ In other words, the feudal past necessarily influenced the feudal present. Living legal structures could be understood only by close study of their origins and the historical process of juristic adaptation in the face of changing social, political and economic circumstances. A contemporary articulation of this principle is provided by the legal humanist François Baudouin who remarked that, "jurisprudence must be joined with history and thereby reduced to fixed law." 3 The legal structures of feudal law had therefore to

1 D.R. Kelley, De origine feudorum: the beginnings of an historical problem, Speculum 39 (1964), p.207-228, at 208

2 Cf. P.A. David, Why are institutions the "carriers of history"? : path dependence and the evolution of conventions, organizations and institutions, Structural Change and Economic Dynamics, 5 (1994), p.205220, at 214-215.

$3[$ A]d certum ius recurrendum est et cum historia coniungenda est iurisprudentia. F. Baudouin, De 
be studied from genesis down to contemporary application with particular attention paid to their reception and adaptation in different historical periods. ${ }^{4}$ History was the scholarly articulation of society's life cycle and historical events had to be interpreted not just for the generalised lessons they might impart but for their capacity to explain how present reality came about in the first place and to explicate the means and process by which past had evolved to present. Humanist writers of the sixteenth century were, as Kelley says, interested in "the living legacy of the past", not in the "archaeology" of dead literature. ${ }^{5}$

For Thomas Craig, then, as a legal humanist, ${ }^{6}$ the study of feudal history was not an end in itself but a means of creating a written institution of living Scots feudal law and practice. That was the core function of his historiographical project. While the Jus feudale was, as the name says, a book on feudal law, Craig applied the legal humanist historical model in a much wider way. In treating the origins of the feudal law, Craig did not begin with the early middle ages when feudal practice first appeared; instead, he went back to Bible to seek the earliest origins of all human law. ${ }^{7}$ From there he traced the development of law from Moses and the Israelites through Egypt and then Greece and Rome, ${ }^{8}$ thence to the law schools of France where it was passed to Scots students in one long process of translatio studii. ${ }^{9}$ Craig was not looking for mere historical precedent for any particular feudal rule, but

institutione historiae universae et eius cum iurisprudentia coniunctione, Paris 1561, p.104

4 D.R. Kelley, The rise of legal history in the renaissance, History and Theory, 9 (1970), p.174-94, at 187 and 192-3.

5 D.R. Kelley, “Fides historiae”: Charles Dumoulin and the Gallican view of history, Traditio, 22 (1966). p.347-402, at 348 .

6 'Humanist' (humanista in Latin, following the mediaeval legista and canonista) is a period term coined by the humanists themselves to describe someone committed to the liberal arts (or studia humanitatis) of classical Rome. Over time, the humanists developed a variety of methodologies and techniques for the study and recovery of ancient learning. The term 'legal humanists' is used here to describe the classically-educated lawyers who, beginning with Alciato, began to apply humanist methodologies to the study of law (a process they knew as the mos gallicus or French method in opposition to the mediaeval mos italicus or Italian method).

7 On this, see L. Dodd, Thomas Craig's aetiology of law and society: literary dependence and independence in the Jus Feudale, Journal of Legal History, 37 (2016), p.121-79, at 127-130.

8 Ibid., passim.

9 J.D. Ford, Law and opinion in Scotland during the seventeenth century, Oxford 2007, p.211-216 and 222223. 
for an authoritative genealogy of the entire concept of law; and any such search demonstrated the ways in law was constantly being adapted to fit new and changing circumstances. It has been said of humanist history that "in contrast to the universalistic claims of philosophy, [it] afforded access to the 'local knowledge' associated with a 'usable past'."10 It is very easy to see why such a model of historical inquiry would be attractive to feudal lawyers, why a form of history that communicated and explained specifically local usages would have value for someone whose professional life was intimately involved with the feudal law, itself a juristic system the expression of which was explicitly local and therefore customary. ${ }^{11}$ Customary law posed certain issues for those utilising humanist literary methodologies, precisely because the humanist method was predicated upon the existence of literature, that is of textual artefacts, that could be studied, analysed and fixed (in both senses of that word). Customary law, however, emerged not from written legal codes but from practical exercises in solving legal problem and resolving disputes. Fortunately for Craig, by the time he began treating this subject, there already existed a great body of predominantly French historicolegal literature discussing in detail the localised application of feudal law, the origins of feudal tenure and the relationship between feudal and learned law. This was the intellectual heritage of the Jus feudale, both the juristic canvas upon which Craig's product was set down and the scholarly inspiration for his own work.

Charles Dumoulin had published "the first comprehensive history of feudalism" in $1539 ;{ }^{12}$ some forty years later, in 1579 , there were sufficient works in circulation on the topic

10 D.R. Kelley, Renaissance humanism, Boston 1991, p.96

11 Jus Feudale 1.11.19, "[T] he feudal law is local and frequently varies according to location" ([J]us feudale locale est et pro diversitate locorum saepissime variatur); cf. also Stair, The Institutions of the Law of Scotland, Edinburgh 1693, p.451: "the feudal law, as hath oftentimes been said...is local". Kelley quotes Bartolus as saying "Today feudal law is nothing but custom set down in writing" (D.R. Kelley, Clio and the lawyers: forms of historical consciousness in medieval jurisprudence, Medievalia et Humanistica, 5 (1974), p.25-49 at 35); his exact citation is unclear to the present author, but the source appears to be Commentaria in primam digesti veteris partem (Basel 1589), p.57 (consuetudo feudorum sit in scriptis redacta) or p.64 (usus feudorum, qui sunt consuetudines, sunt redacti in scriptis).

12 Kelley, The rise of legal history (supra, n.4), p.189 
that the Italian humanist and feudist Marino Freccia felt it necessary to produce a summary of the opinions of contemporary feudal historical writers. ${ }^{13}$ The effect of so many differing historico-legal interpretations was to underline the complexity and variety of European feudal customs and traditions and to inspire lawyers like Craig in their efforts at establishing authoritative accounts of their own local customs. If we do no more than note the number of writers and texts explicitly cited in the Jus feudale, it is abundantly clear that Craig was part of and dependent upon a much larger historiographical tradition which served as inspiration, model and frame for his own studies into Scotland's legal history. ${ }^{14}$ While the scale of his achievement and originality of his analysis mean that he fully warrants being recognised as a significant legal humanist scholar in his own right and the father of Scots institutional and legal historiography, he was not the inventor, discoverer or originator of historical inquiry into the origins of feudal law and tenure. ${ }^{15}$ Indeed, the earliest attempt to uncover the historical origins of the feudal law was that of Baldus and therefore pre-dates both humanism and the Renaissance. ${ }^{16}$ Within a specifically Scottish context, there were clear attempts to locate and define the origins of feudal tenure as early as the mid-fourteenth century. Both in the Leges Malcolmi Mackenneth and in the Chronica gentis Scotorum of John of Fordun, we find accounts that involve King Malcolm II giving away all his land to the barons, in return for wardship and relief, while keeping for himself only the moot hill (or mound of pleas) at Scone. ${ }^{17}$ Craig was thus neither the first humanist nor the first lawyer nor even the first Scot to attempt to give an account of the origins of feudal tenure and law. He was merely the latest

13 M. Freccia, De subfeudis baronum et inuestituris feudorum. Venice, 1579; cf. Kelley, De origine feudorum (supra, n.1), p.210

14 Douglas Osler has pointed out that Europe in this period was so riven by political and religious differences that scholars could and did work in complete ignorance of the efforts of colleagues in other countries (D. Osler, The Fantasy Men, Rechtsgeschichte, 10 (2007), p.169-190 at 184). Craig, of course, was wholly conscious of and to a large extent reliant on the literary product of French legal humanists.

15 Kelley observes a disheartening tendency to ignore the pre-Enlightenment historiographical contribution which, amongst other things, has led to the myth that Montesquieu originated the idea of feudalism in L'esprit des lois; see Kelley, De origine feudorum (supra, n.1), p.207.

16 Ibid., p.214; see also Kelley, Clio and the lawyers (supra, n.11), p.25-26 on the "historical consciousness" of mediaeval lawyers.

17 H.L. MacQueen, Tears of a legal historian: Scottish feudalism and the ius commune, Juridical Review, 1 (2003), p.1-28, at 21; and H.L. MacQueen, Common law and feudal society in medieval Scotland, Edinburgh 2016, p. 86 . 
in a long line of legal thinkers to approach the topic.

\section{The ancestry of the feudal law: competing theories}

The origins and development of law form a significant part of the first book of the Jus feudale. ${ }^{18}$ The first title treats the emergence of law and legal processes in the earliest human societies while the second and third title deal with the Roman and canon law respectively. It is in the fourth title that Craig discusses the genesis of feudal law and tenure. This is followed, in the fifth title, by a very short refutation of those who ascribe a Roman origin to the feudal law. The sixth deals with the origins of written institutions of feudal law, meaning the Libri feudorum, the twelfth-century Lombard text which served as the principle written source on feudal custom. ${ }^{19}$ Titles seven and eight deal respectively with the feudal law's arrival and application in the British Isles. In other words, approximately half of the first book deals with matters that might be described as introducing the history of law rather than the living law. One might have supposed that a practising lawyer would begin a study of the feudal law by discussing the key written institution of feudal law, the Libri feudorum, particularly in view of its influence on the development of Scots law, ${ }^{20}$ but Craig's approach was typical of the humanist methodology. While his primary interest was certainly in living legal practice, he conceived of law as a phenomenon that could be understood only in terms of its full historical development. The proper starting point for a humanistic discussion of the feudal law was therefore with its origin.

18 A new English translation and Latin edition of the text has recently been published by the Stair Society: T. Craig, Jus feudale tribus libris comprehensum [=Stair Society, vol. 64], ed. \& trans. L. Dodd, Edinburgh 2017.

19 The point has been well made that the Libri feudorum was a local Lombard text and we should be careful not to overestimate its influence (see D. Heirbaut, Feudal law in: The Oxford handbook of European legal history, H. Pihlajamäki, M.D. Dubber and M. Godfrey, Oxford 2018, p.529-548, at 538); but, even so, it served a useful function for early modern lawyers by providing a fixed point of reference.

20 MacQueen, Common law (supra, n.17) p.117-118 and 264 
The heading of the fourth title is De origine et progressu feudorum ("On the origin and development of feus"). This communicates something about about Craig's understanding of and historiographical approach to the subject. In the first place, it indicates that law was to be understood as the product of an extensive process of historical evolution. ${ }^{21}$ Texts such as the Libri feudorum were themselves the result of this process and therefore could never be accurate guides to the earliest manifestations of feudal practice. The feudal law was construed as a tradition stretching from shadowy beginnings in the early middle ages all the way down to the Scotland in which Craig lived, worked and wrote. It had never been a fixed structure, but was instead adapted to meet the needs of particular places and periods; even the Jus feudale itself can be seen as a part of that process of legal evolution, that is, as an effort at defining and articulating "the amorphous mass of feudal customs" utilised by the civil courts of early modern Scotland and reducing them to a fixed, crystallised format. ${ }^{22}$ While all feudal law was fundamentally alike in that it used the same terminology to describe the same basic forms of tenure and service, the specifics varied enormously from century to century and from place to place. ${ }^{23}$ The Libri feudorum was therefore no more than the articulation of a developed system of feudal law and tenure in one specific place at one specific point in time. The true origin of the feudal law was much earlier. By Craig's day, a number of competing humanist theories had emerged about the origins of feudal law and tenure, of which two are particularly important: one believed that the foundations of feudal law lay in the Roman empire and the other that they were to be found in ancient Germany. These theories formed the scholarly background to Craig's work and to some extent circumscribed his engagement with the topic.

21 Cf. J.W. Cairns, T.D. Fergus \& H.L. MacQueen, Legal humanism in renaissance Scotland, Journal of Legal History, 11 (1990) p.40-69 at 51-52; and H.L. MacQueen, Regiam majestatem, Scots law, and national identity, Scottish Historical Review, 74 (1995) p.1-25 at 15-16.

22 D. Baird Smith, Sir Thomas Craig, Feudalist, Scottish Historical Review, 12 (1915), p.271-302, at 285

23 G.L. Gretton, The feudal system, in: The Laws of Scotland: Stair Memorial Encyclopaedia, Edinburgh 1996, vol. 18 , para. 44 
The earliest iteration of the Romanist position was with Budé in his Annotationes in XXIV libros Pandectarum of $1508,{ }^{24}$ "a sprawling collection of notes" on the first twenty-four books of Justinian's Digest. ${ }^{25}$ Budé believed that the ancestor of the feudal system lay in the ancient Roman system of clientage, which involved individuals pledging themselves to powerful patrons as clients. The two would then be bound by informal sets of duties, rights and obligations. The patron became the client's protector, providing legal representation, loans, political support and so on; the client, in turn, had to serve his patron as necessary, for example by voting for him in elections or paying ransom if the patron was captured. Each was bound to refrain from doing the other any harm. Superficially one can see that similarities existed between clientage in classical Rome and mediaeval vassalage, but, apart from that, the Romanist position provided feudal tenure with a prestigious historical pedigree. ${ }^{26}$ Under the Romanist position, feudal practice was not to be seen as a barbarous innovation of the middle ages but as a surviving aspect of the ancient world; for Renaissance humanists, to whom the mediaeval period was a dark age of ignorance, superstition and pedantry, the prospect of a classical origin for feudal law was obviously very attractive. Even for those who rejected Budé's association of vassalage with clientage, a Roman genesis was still appealing because it made the feudal law into a descendant of the civil law and thus the intellectual progeny of imperial Rome. Cujas, probably the most famous of the French legal humanists, presented the next important iteration of the Roman theory; ${ }^{27}$ for him, feudal law and tenure descended not from clientage but from certain forms of perpetual tenure found in late Roman law. ${ }^{28}$ The ancestors of the mediaeval vassals were thus the actores, custodes and coloni of the Corpus iuris civilis. An opposing position was articulated by the Germanist

24 Kelley, De origine feudorum (supra, n.1), p.218

25 K. Davis, Periodization and sovereignty: how ideas of feudalism and secularization govern the politics of time, Philadelphia 2008, p.35

26 Kelley, De origine feudorum (supra, n.1), p.217

27 On the life and works of Cujas generally, see X. Prévost, Jacques Cujas (1522-1590), jurisconsulte humaniste, Geneva 2015.

28 Kelley, De origine feudorum (supra, n.1), p.219 
thesis first espoused in 1539 by Dumoulin in his treatise De feudis, a study of and

commentary on Parisian customary practice; he was the first to discern a link between

mediaeval vassalage and the armed tribal retinues (or comitatus) described by Tacitus in the

Germania. ${ }^{29}$ Other theories arose - such as Connan's which, drawing upon Caesar, attributed

the beginnings of feudal tenure to the ancient Gauls - but the Germanist and Romanist

paradigms had no serious competitors. When François Hotman came to publish his feudal

commentary in 1573, he further developed the Germanist line and presented it in its

"classical form". ${ }^{30}$

Craig had read Dumoulin, Cujas and Hotman and indeed repeatedly mentions each by name, so, by the time he began writing the Jus feudale, he was fully conversant with these competing theories. ${ }^{31}$ Hotman, however, was far and away Craig's favourite source on feudal law and history. ${ }^{32}$ Kelley has argued that the Germanist thesis in general, but particularly Hotman's version, "was distorted by ideological bias" and articulates an avowedly religious message that exalts "the liberties and virtues of the Germans (by inference the Protestants) above the perfidious Romanists"; even the failure of Connan's "gaulois theory" is explained

29 On Dumoulin generally, see Kelley, "Fides Historiae” (supra, n.5), p.352-356.

30 Kelley, The rise of legal history (supra, n.4), p.190. While it is generally accepted that Hotman traced the concept of vassalage back to the tribal comitatus described by Tacitus, Pocock argued that Hotman was resistant to this idea (J.G.A. Pocock, The ancient constitution and the feudal law, Cambridge 1957, p.77-78). He bases this on a section of Hotman's Disputatio de iure feudali (pp.17-19 in the 1574 Cologne edition of the De feudis commentatio tripartita, to which all future citations refer) where he believes that Hotman is stating that barbarian retainers could not be the $u r$-vassals of feudalism because, after settling in the empire and receiving allotments of land, they became unfree coloni bound to the land in the same manner as serfs. Since they were no longer free, their position could not be said to be analogous to that of feudal vassals. This is a rare instance where Pocock's interpretation seems to be wide of the mark since Hotman is not, in fact, talking about comitatus at all but about actores, custodes and coloni. Specifically, he is attempting to refute "the opinion of those who argue that the origin of vassalage derives from the Roman law because in the books of the Codex mention is made of actores, custodes and especially coloni, to whom fixed lands were assigned them in perpetuity" (Superest eorum sententia, qui disputant vassalos propterea ex jure Romano sumpsisse, quoniam in libris Codicis mentio sit actorum, custodum et praecipue colonorum quibus agri certi ea conditione in perpetuum attributi erant). It is significant that Hotman does not actually use the word comitatus to describe those who became coloni; indeed, the most proximate appearance of the word comitatus is in the previous chapter, some five pages earlier (p.12).

31 Despite this and other uses of Dumoulin, Sir John Skene was methodologically far closer to Dumoulin than Craig ever was; see Ford, Law and opinion (supra, n.9), p.264.

32 J.W. Cairns, The breve testatum and Craig's Ius feudale, Tijdschrift voor Rechtsgeschiedenis, 56 (1988), p.311-332, at 330; D. Baird Smith, François Hotman, Scottish Historical Review, 13 (1916), p.328-365, at 351-352. 
as a consequence of "the explosive anti-Romanist pressures of the wars of religion". ${ }^{33}$ Such an interpretation is not without problems, ${ }^{34}$ but if we assume its validity, then it would impart a religious dimension to the existing intellectual and cultural kinship which Craig clearly felt for French legal humanists and their literary product. The version of the feudal past expressed in the Jus feudale must be seen as part of the broad web of legal humanist thought; that is, as the function and expression of contemporary discourse, not as something subordinate to that discourse. Craig was no mere recorder of the opinions of others, but an insightful interpreter of history who drew upon the wider corpus of scholarly literature to articulate and contextualise his own work and thought. Pocock has rightly praised "the breadth and clarity of Craig's historical thought", ${ }^{35}$ but it is important that our reading of Craig also includes appreciation of the independence of his analysis.

\section{The Germania as feudal source}

Like Hotman and Dumoulin, Craig believed that the origins of feudal practice lay in ancient Germany and his primary source on this topic was Tacitus' Germania. The earliest echo of the feudal relationship between lord and vassal lay in the relationship between master

33 Kelley, The rise of legal history (supra, n.4), p.189-190

34 It is the case that some Protestant German humanists treated the Germania as a repository of moral ideals which their nation and denomination should emulate (see C. B. Krebs, A most dangerous book: Tacitus' Germania from the Roman Empire to the Third Reich, London 2011, p.125-128), but it must be remembered that Tacitus' entire purpose in writing the Germania was to contrast, for rhetorical purposes, the virtues of Germanic barbarism with the seeming decadence and servility of Roman civilisation and that he did much the same thing with his account of Roman Britain, the Agricola. Hotman therefore inferred little that Tacitus did not explicitly state. He may have seen the text as having particular relevance to the contemporary religious and political reality, but that is a matter of reception, not distortion and, in any case, there is nothing explicit in Hotman's text to suggest that this was the case. The success of the Germanist thesis can be explained by the simple fact that it was objectively more plausible than Connan's Celtic origin story or the wishful thinking of those who wanted feudal tenure to become a relic of the Roman empire. Apart from anything else, if the belief that the origins of feudal law are to be found in the Germania is a specifically Protestant position that articulates hostility to Catholicism, we must wonder why so many Catholic feudal lawyers embraced the theory enthusiastically. As Douglas Osler has stated, the tendency to treat legal humanism as a predominantly Protestant phenomenon ignores the significant part played by southern European Catholic lawyers; see D Osler, Legal Humanism, Max-Planck Institute (http://www.rg.mpg.de/research/legal-humanism).

35 Pocock, The ancient constitution (supra, n.30), p.88 
and slave. ${ }^{36}$ Within Craig's sociological model, slavery had arisen in prehistory, along with warfare and the laws of nations, and was common to all human societies, ${ }^{37}$ but its implementation and the relative rights of slave and master varied from place to place, as did the attitudes of the enslaved. In this case, there existed a distinction between the forms of slavery practised by the Romans and what Craig perceived as the milder forms found among the ancient Germans. Roman slavery was characterised by the master's unlimited power over his slaves, his right to use and abuse his human property as he saw fit and by the servility of the enslaved. Thus he states that "[a]mong the southern peoples, slavery was harsh and the authority of masters grievous; and the further south one went, the more scandalous was the condition of the slaves, for the master had absolute power of life and death, while the slaves had nothing that could be called their own and were beaten down and compelled to support their masters through their labour in workshops and mills, that is, in the vilest and most wretched employments of grinding and ploughing at their masters' whim." ${ }^{38}$ In the north, however, among the Germans, the institution of slavery was both less common and much less harsh and the people themselves were less tolerant of encroachments upon their personal liberty. So while the Roman slave lived in his master's house and performed domestic functions, the German slave was more akin to a tenant and had his own house, land and family which he governed as though free. Instead of performing domestic duties for his master, the German slave provided a specific and fixed amount of grain, cattle or cloth and could not be compelled to surrender anything beyond that. Germanic slavery lacked most of the characteristics that a modern readership associate with the institution; while the slave was subordinate to his master in certain respects, he retained clear sets of rights against which his

38 JF 1.4.2: [A]pud populos meridionales dura erat servitus, dominorum imperia gravia; quoque magis ad meridiem declinabant, servorum conditio fuit iniquior; in quos libera erat dominis vitae et necis potestas; nihil illi quod suum, nihil quod proprium dici posset, habebant et ad ergasteria et pistrina, id est, ad vilissima et miserrima ministeria molendi et arandi pro dominorum arbitrio detrudebantur, dominos suis laboribus alere coacti. 
master could not transgress. Above all, one cannot usefully speak of German masters as owning their slaves, with the full property rights that such a term would imply. Craig tells us that this reflected what the ancients saw as the northerners" "intolerance of servitude" by contrast with the more servile southern nations whom he describes (quoting the poet Lucan) as "weakened by the mildness of the climate" (emollit gentes clementia coeli).

The discussion of the supposed relationship between climate and national character had deep roots in Western thought. The earliest iteration of this idea is found in a text of Hippocrates, from the fifth century BC, named On Airs, Waters and Places though the idea was taken up by, amongst others, Plato. ${ }^{39}$ The most famous formulation of climate theory, however, was that of Aristotle in the seventh book of the Politics. Predictably, the Aristotelian articulation of climate theory was accepted as authoritative by a great many authors, both ancient and modern. ${ }^{40}$ Among the humanist writers, the Aristotelian theory of climate was a relatively common topic for discussion; so, for example, Buchanan's De jure regni apud Scotos mentions both the seeming servility of Asiatic peoples and the superior intelligence of people from warm climates. ${ }^{41}$ Tacitus utilised this same basic theory of climate in the Germania to explain the moral differences that he perceived between Germans and Romans. As one classicist describes matters, it was as though "the degree of morality stood in inverse proportion to degrees Fahrenheit." ${ }^{22}$ Although Tacitus was Craig's primary source on climate, it is augmented in places by material from less famous Latin authors, such as Vitruvius and Vegetius. ${ }^{43}$ It is not necessarily the case that Craig had read these more obscure sources directly and it may be that he derived them from Bodin's Methodus ad facilem historiarum

39 J.K. Ward, Ethnos in the Politics: Aristotle and race, in: Philosophers on race: critical essays, eds. J K. Ward and T.L. Lott, Oxford 2008, p.14-37, at 20

40 For example, the Book 14 of Montesquieu's L'esprit des lois is titled Des loix, dans la rapport qu'elles ont avec la nature du climat ("On laws and their relationship to the nature of climate").

41 G. Buchanan, De jure regni apud Scotos, p. 8 on warmer climates and intelligence; p.145 on Asiatic servility (all references to the 1750 Glasgow edition).

42 Krebs, A most dangerous book (supra, n.34), p.159

43 Cf. Craig, Jus feudale (supra, n.18) p.89, n.6. 
cognitionem, which discusses the relationship between climate and character at length, both in general terms and with particular reference to the ancient Germans. ${ }^{44}$ Bodin was a favoured source for Craig's work, one he both cited and recommended to his own readers. ${ }^{45}$ Our interpretation of Craig's feudal history should recognise the part played by contemporary humanist literature in framing both the conversation and its immediate reception. So while the Germania was the primary source, its interpretation and presentation were informed by a wider body of scholarly thought. This becomes clearer still as Craig moves on to analyse differences in the Roman and German treatment of slaves.

Where a Roman master had the legal power of life and death over his slaves - the infamous vitae necisque potestas - a German master did not. Craig is emphatic on that point. A German might kill his slave in the heat of the moment, because he was angry or had been provoked, but he had no implicit or explicit right to kill a slave. Such a distinction may be subtle, since the slave would be dead in either case, but it is nevertheless important. Craig was articulating the classical ideological position that Romans were reasonable, rational humans who had mastered their passions whereas barbarians were erratic and driven entirely by their emotional impulses. ${ }^{46}$ Hence there could be no equivalence of moral culpability between the civilised Roman who coolly chooses to kill a slave and the German barbarian who kills accidentally after lashing out in anger. This, too, is a topic discussed in Bodin's Methodus where it is explained that Germans were, by nature, more like beasts than men: "He who is removed from humanitas (that is, from the nature of humans) is much the same as a beast, since beasts lack reason and are unable to restrain their temper and passion." ${ }^{47}$ The

44 Bodin, Methodus ad facilem historiarum cognitionem, Paris 1572, p.119-125.

45 See Dodd, Craig's aetiology (supra, n.7), p.149, 168, 171, etc., for instances of Craig utilising the Methodus.

46 P.J. Heather, The barbarian in late antiquity: image, reality, and transformation, in: Constructing identities in late antiquity, ed. R. Miles, London 1999, p.234-258, at 236; and G. Woolf, Power and the spread of writing in the West, in Literacy and power in the ancient world, eds. A. Bowman and G. Woolf, Cambridge 1994, p.84-98, at 84 .

47 Bodin, Methodus (supra, n.44), p.140: Quisque plus abest ab humanitate, id est, ab hominum natura, eo proprius ad ferarum similitudinem accedit, quae cum ratione careant, iracundiam et appetitus cohibere nequeunt. In this instance, note that humanitas can be translated as 'civilisation' or 'humanity' and was the 
corollary of this is that when Germans killed, they did so not from cruelty but from anger and, as a source for this, Bodin quotes the very same section of Tacitus as Craig; ${ }^{48}$ a few pages later, Bodin repeats the point but adds that northern peoples, though temperamental, were quickly and easily placated while southern peoples generally acted coldly and with vulpine cunning (vulpina callidate).$^{49}$

Slavery among the Germans was sufficiently mild that individuals would stake their liberty during dice games. Craig relates this form of debt slavery to a similar practice among the early mediaeval Lombards, described using noun guadium or vadium ('pledge'), whereby anyone who could not repay a debt became the king's slave. ${ }^{50}$ Following this, he cites Bodin as saying that those enslaved in this way, or their families, could buy freedom by settling the outstanding debt. ${ }^{51}$ The starkest difference between Roman and Germanic slavery - and certainly the difference which was of most importance to a feudist - was to be found in the military sphere, for while Romans forbade their slaves from military service on pain of death, German masters routinely armed their slaves and took them to war. In addition to slavesoldiers, Craig quotes Tacitus as saying that Germanic chieftains recruited and maintained comitatus or retinues of fighting men who would live alongside their chief, eating at his table and receiving all their necessities for him; in return, they acted as a bodyguard: "To guard [the chieftain], to protect him, to dedicate their own brave deeds to his glory: this is their special vow." He finishes this section (JF 1.4.3) by stating explicitly, "[T]he northern nations treated their slaves as though they were retainers or at least tenants, imposing on the weaker ones a customary annual payment whether of money or grain or cloth, which the masters, in

standard term to describe the literary product and culture of ancient Rome.

48 Ibid.: Occidere solent, inquit [Tacitus], non disciplina et severitate sed impetu ac ira ut inimicum.

49 Ibid., p.145.

50 Craig's likely source on this is Hotman, Dictionarium verborum feudalium (=p.742 in 1574 Cologne edition).

51 Probably referring to Bodin, Methodus (supra, n.44), p.141, which quotes the same section of Tacitus that Craig uses. 
turn, passed to the stronger servants as though in place of a wage. Nothing happened either at home or on campaign without them: at home they attended the assembly, and on campaign they contributed their efforts and their strength." Slaves are thus split into two groups with different duties and rewards. The weaker slaves were indistinguishable from tenant farmers; they worked the land and paid a fixed and limited amount of what they produced to their master, but the rest was their own and they ruled their own homes independent of their master's will. The stronger slaves fought and in return received grants of food, money and clothing. Chieftains also maintained groups of free retainers bound to them by vows of martial loyalty. From this material, it is easy to see the direction that Craig's mind was taking. In Tacitus' description of ancient German society, he saw a reflection of mediaeval feudal practice.

Given the centrality of the Germania to Craig's argumentation, some explanation is needed of its position within humanist thought on law and history. Long before Craig started work on the Jus feudale, the humanists had found Tacitus to be an invaluable source. The father of the legal humanist methodology, Andrea Alciato, published an edition of Tacitus in 1517 in which he praised the author as the best Roman historian and superior by far to Livy. ${ }^{52}$ Alciato's focus was entirely on the civil law, so Tacitus' work was valuable to him because it illuminated the historical context in which the Roman law had functioned. Alciato's students and successors applied the humanist methodology to the study of French municipal and feudal law, ${ }^{53}$ but they also found a politically topical use for Tacitus, employing the

52 J.H.M. Salmon, Cicero and Tacitus in sixteenth-century France, American Historical Review, 85 (1990), p.307-331, at 310; N.G. Siraisi, History, medicine, and the traditions of renaissance learning, Ann Arbor 2007, p.158. A contrary view existed, so the humanist Budé derided Tacitus as the worst of all historians, largely because he was a pagan who had criticised Christianity. Bodin discusses the matter in the Methodus (supra, n.44), p.95-96.

53 C.P. Rodgers, Humanism, history and the common law, Journal of Legal History 6 (1985) p.129-56, at 131; see also Kelley, The rise of legal history (supra, n.4), p.187 and 192-3; Pocock, The ancient constitution (supra, n.30), p.13-14; and M. Stuckey, Early modern English humanism and antiquarianism: the prosopographical method and reflections on historico-legal tradition, Journal of Legal History, 33 (2012), p.31-64, at 59. See J.L. Brown, The Methodus ad facilem historiarum cognitionem of Jean Bodin: a critical study, Washington 1939, p.29-45 for the ways in which Bodin's dissatisfaction with the humanist emphasis 
Germania to advance a new set of historical theories about the origins of their country and its institutions. France's mediaeval foundation myth was to be found in the seventh-century Fredegarii scholastici chronicum or Chronicle of Fredegar which assigned the origin of the Carolingian dynasty and, therefore, of the Franks to a Trojan prince named Francus (a synonym of Astyanax, the son of the Trojan hero Hector). Other mediaeval texts repeated versions of this story - for example, the Liber historiae Francorum, the Historia Britonnum of Nennius and, during the later middle ages, the Grandes chroniques de France. French legal humanists rejected these fantastic and implausible romances and sought an alternative and historically credible explanation of Frankish and therefore French origins. ${ }^{54}$ They found it in what Kelley has described as the "Germanist paradigm" which drew upon classical writers like Tacitus and the more obscure "barbarian historians" of late antiquity, such as Jordanes, to reconstruct the Franks as a Germanic tribe who had crossed the Rhine and settled in Gaul in the early middle ages. ${ }^{55}$ This excavation of the authentic beginnings and history of the Franks served specific political ends, particularly as it related to royal power and religious liberty ${ }^{56}$ importantly, the humanist reconstruction of French history extended to France's entire national identity and all the things related thereto, which, of necessity, meant the extant system of feudal tenure and the law by which it was governed. For Craig's purposes, this is the single most important aspect of the humanist investigation of Frankish history: it introduced him to the idea that feudal tenure originated in ancient Germany.

The Germania, as we have said, was a primary source not only for Craig but also for

on Rome drove him to develop his own approach to the study of law and history.

54 For example, Hotman in the Francogallia dismisses the Trojan origin story as poetry, not history (p.34 of the 1586 Frankfurt edition). It is interesting to note that the English historian William Temple, writing in the seventeenth century, designated one Pharamond as the founder of the Frankish nation (C. Kidd, British identities before nationalism: ethnicity and nationhood in the Atlantic world, 1600-1800, Cambridge 2005, p.244-5); while Pharamond was no less legendary (or no more historical) than Francus, his existence was attested by Gregory of Tours whose work was seen as more historically authentic. This search for plausibility defines the work of humanist historians.

55 D.R. Kelley, Faces of history: historical inquiry from Herodotus to Herder, London 1998, p.179-180; cf. Krebs, A most dangerous book (supra, n.34), p.158-159

56 I. Wood, The modern origins of the early middle ages, Oxford 2013, p.11-12 
many other historians of the feudal law. It was a text that had been written with a particular agenda which Craig fully internalised. Tacitus, above all else, was a moral writer and his work was intended to critique what he saw as the shortcomings of contemporary Romans by contrasting their decadence with the supposed virtues of the Germans (primarily sexual constancy, personal loyalty, fortitude, physical courage and a devotion to liberty). ${ }^{57}$ This was, in effect, the earliest iteration of the literary trope of the Noble Savage and that was the lens through which Craig viewed ancient German society. Nor was he alone in doing so. A great many sixteenth century writers embraced the contrast between the innate honour and decency of Noble Savages and the cruelty and brutality of contemporary Christians, particularly within the context of the French wars of religion. ${ }^{58}$ Craig read the Germania within a Scottish feudal context and therefore invested it with relevance specific to those circumstances and to the compositional function of the Jus feudale. He asserts that what Tacitus said of the Germans was in fact true of "all the northern nations", which of course includes the Scots, ${ }^{59}$ and quotes the Roman emperor Julian as saying, "You see how the Syrians freely serve other nations and, by contrast, how great is the love of liberty among the Celtic peoples." 60 This same remark is quoted, in nearly identical words, by Bodin and Cujas, both of whom Craig had read, ${ }^{61}$ but, as a Scot, Craig imbued the comment with a meaning it might not have had to

57 Cf. Salmon, Cicero and Tacitus (supra, n.52), p.309

58 Montaigne, who is often erroneously thought of as the inventor of the trope, is the best-known example, but there are a great many others. On Montaigne's use of this literary device, see T. Cave, How to read Montaigne, London 2007, p.81-82; D. Quint, Montaigne and the quality of mercy: ethical and political themes in the Essais, Princeton 1998, p.92-99; and A. Levine, Sensual philosophy: toleration, skepticism, and Montaigne's politics of the self, Lanham 2001, p.105-107.

59 Tacitus was the first ancient author to make a distinction between Celts and Germans. Certain writers of the seventeenth century attempted to fold the two groups back into one another. Thus, the German humanist Philipp Clüver (1580-1622) said in his Germania antiqua that the Germans were a branch of the Celtic family (= p.41 in the 1616 Leiden edition) while the English historian William Temple discerned similarities between the ancient customs of the Germans and those of contemporary Scots and Irish, whom he held to be of "northern Scythian" and hence Germanic stock (Kidd, British Identities (supra, n.54), p.196). As late as the $19^{\text {th }}$ century, the English-born German nationalist and völkisch writer H.S. Chamberlain envisioned Tacitus' Germans as encompassing Celts and Slavs as well as the modern German nation (Krebs, $A$ most dangerous book (supra, n.34), p.209-210).

60 JF 1.4.3, Sic Julianus apud Cyrillum, Vides, inquit, quam libenter Syri aliis nationibus inserviant, contra vero quantus libertatis amor in Celtarum populis.

61 Bodin, De republica, p.42 (1586 Paris edition); Cujas, De origine et natura feudorum dissertatio (vol. 2, p.1045 of the 1758 Venice Opera). 
writers of other nations. Similarly, he wholeheartedly embraced the idea the colder northern climate bred a tougher, more robust and decidedly warlike people. ${ }^{62}$ Craig quotes a portion of Lucan's Pharsalia which describes the northern peoples as "untameable in war" (indomitus bellis) and focused entirely on martial virtues (apud eos omnia in virtute militari posita). It is likely that these descriptions reminded him of the people of his own country; ${ }^{63}$ or, more exactly, it reminded him of the way that the Scots wished to see themselves and to be seen by others, as a freedom-loving, martial and headstrong people whose social morality echoed that of the ancient Germans whom Tacitus so respected. ${ }^{64}$ The perception of the Scots as existing at some distance from mainstream European civilisation had been commented on by George Buchanan, who rather meekly observed that while those in the north had no great reputation for intellect, being at such a remove from "literature, culture and all cultivation of the mind", ${ }^{65}$ no nation had been completely deprived of intelligence and, in any case, Scottish shortcomings in matters of the mind were explained by the fact that foreigners were less emotional and therefore less prone to be distracted from intellectual discussion. With the Germania, Craig was able to construe the perception of Scotland as a place outside the bounds of normal European civilisation in a positive way, as a marker that their supposed removal from civilised norms actually amounted to a removal from the sphere of decadence, servility and general immorality. In multiple ways, therefore, Craig, the early modern feudal lawyer, was trying to connect the ancient past to his contemporary Scottish experience.

62 This theory is discussed at excessive length by Bodin in the fifth chapter of the De republica and in the Methodus ad facilem historiarum cognitionem (supra, n.44): p.119-125 on the link between climate and physical character and p.133 on the German love of war. For later use of the trope, see Krebs, $A$ most dangerous book (supra, n.34), p.171-172.

$63 \mathrm{Cf} . J F$ 1.11.3 where he compares the armour of the ancient Greeks to that of contemporary Highlanders.

64 Tacitus' other minor work is the Agricola, which deals with the Roman conquest of Britain and represents the earliest literary portrait of the Celtic inhabitants of what would later become Scotland. Craig was familiar with the text and drew upon it in writing both his dedicatory epistle to the Jus feudale (see Epistola nuncupatoria auctoris, in Craig, Jus feudale (supra, n.18), p.lviii-lxxix, at lxx [Latin] and lxxi [English]) and his text on the British union, the De unione regnorum Britanniae. He does not utilise the Agricola here because it had no direct relevance to a discussion of the origins of feudal law and tenure, but the text certainly influenced his thinking.

65 A literis, humanitate, omnique ingenii cultu homines..., Buchanan, De jure regni (supra, n.41), 8. 


\section{The infancy of the feudal law}

If the ancestor of vassalage was the Germanic comitatus whereby retainers fought for their chiefs and in return were provided with everything they needed to live, the question remains of how this social structure was transplanted from first century Germany to mediaeval Europe where it evolved from the relatively primitive system of military clientship described by Tacitus into an articulated form of land tenure and law. The journey from tribal to feudal society began, for Craig, with the barbarian invasions of the Roman empire in the fifth and sixth centuries. He explains that Goths, Vandals, Huns, Lombards and other barbarian groups divided up the provinces of the empire between them and in the process displaced existing Roman practice. ${ }^{66}$ For greater context, it should be noted that Bodin also dealt with the barbarian invasions of the Roman empire and covered the same material as Craig. Bodin, however, approached the aftermath of the barbarian invasions from the perspective of the relative intellectual and cultural capacity of the invaders and the peoples they subjugated, explaining that the barbarians were more effective as soldiers than as rulers; ${ }^{67}$ though eminently capable of conquest, they lacked the ability to rule effectively and were compelled to appoint civilised men as ministers. ${ }^{68}$ While we can be reasonably certain that Craig had read and understood these parts of the Methodus, his interest was less diffuse than Bodin's and focused only on the transition to a feudal society.

Consequently, Craig's account is quite straightforward. Having divided up the Roman provinces amongst themselves, the barbarian leaders would dole out land to their weaker servants in return for rents of oil, grain, cattle, cloth and money. The chieftain's strongest followers became his personal companions or retainers and were paid in kind for their

$66 J F 1.4 .4$

67 Bodin, Methodus (supra, n.44), p.140

68 Ibid., p.138 
service, since monetary wages had not yet developed. To that extent, Craig's description of early mediaeval German society west of the Rhine is identical in its main particulars to Tacitus' description of ancient German society east of the Rhine. The difference, and the genesis of feudal tenure, came later when, in place of the fruits of the chieftain's lands, the retainers were given the actual estates from which their payments were drawn. As Craig puts it, "There seemed to be no difference to the lords whether they conferred the land itself or all the fruits and profits derived from the land, as it would nevertheless always be in their power, should they wish, to take away either the estate or the payment that had been given in feu." 69 It is the grant that is here described a feu, not the land itself, and these tenants had no more than a precarium jus or precarious right over the land they occupied; ${ }^{70}$ it could be revoked by the true owner, the retainer's lord, as and when he wished. The tenants are described by Craig as servants (servientes) and are distinguished from slaves (servi); he helpfully explains that where slaves are subject to servitus (slavery), the servant is bound merely to servitium (service).$^{71}$ Where the slave was wholly owned by his master, the servant was bound only "to provide faithful labour and sometimes to proffer help and advice.” To an extent, we can see that Craig is anticipating Marx in describing the transition from the ancient slave economy to the early mediaeval feudal economy and it is, in fact, of central importance to Craig's argumentation that there exists a meaningful and material difference between the ancient and mediaeval worlds, between pre-feudal and feudal tenure. Accordingly, he seeks to differentiate between Roman slaves and Germanic servants (or serfs) and between the forms of labour they owed and the levels of power that their masters had over them. ${ }^{72}$ It is likely that in writing this section Craig was drawing upon Hotman's dictionary, which provides

$69[N]$ ihil dominorum interesse videretur, utrum res ipsas an fructus omnes ac utilitates rei assignarent; sic tamen ut in dominorum semper esset potestate aut ipsum praedium aut pensionem in feudum datam quando vellent auferre.

70 On the precarium, cf. F.L. Ganshof, Qu'est-ce que la féodalité?, Neuchâtel 1947, p.27.

71 Craig's definitions are correct only in mediaeval Latin; in classical Latin, both servitus and servitium mean 'slavery'.

72 Thus, Gretton, Feudal system (supra, n.23), para. 43, notes that while the earliest form of vassalage "was in some ways like slavery...nonetheless there was a clear distinction between the vassal and the slave. The vassal was a free man." 
specifically feudal definitions of both servire and servitium..$^{73}$

It came to be seen as unfair that tenants could be dispossessed at their lord's whim, so a fixed form of tenure was introduced, initially for one year. ${ }^{74}$ This was the next step in the development of the feudal law and the evolution of feudal tenure. Craig describes the lands given in this way as "annual feus" (feuda annalia) and this is important because it is here, for the first time, that the word feudum is used to describe land held or leased from another. He explains that, "[a]s time went by, the merits, or the insolence, of servants arranged it so that feus began to be given for life; that is, they were granted by the lord to the client for the duration of his lifetime, with contracts introduced between lord and servant regarding their mutual obligations. These feus could truly be called usufruct. They also constitute the original cradle of feudal law." 75 Lifelong tenure, Craig explains, was akin to the Turkish timar, the system of land tenure whereby a benefice was granted by the Ottoman state to a horseman (or sipahi) in return for military service. It is striking that Craig should try to explain early feudal practice by analogy to then-contemporary Turkish practice. ${ }^{76}$ The timar, which Craig describes with surprising accuracy,${ }^{77}$ did bear some resemblance to European feudal practice - although, and certainly from a Marxist perspective, it could be argued that the timar was not a feudal institution at all and actually represented a state effort to avoid the

73 Hotman, Dictionarium verborum feudalium, s.v. servire and servitium : [Servitium est] [m] unus obsequii clientelaris. Similiter potest feudum dari ad certum servitium... Proprie servitium est officium servile... Itaque, feudale officium vel obsequium libentius appellavimus. Nam saepe servitii nomine officium affectionis significationis significatur, ut illud quod imperii vasalli imperatori suo debent. ("[Service is] the duty of an obedient client. A feu can be given in return for fixed service... Properly, service is servile duty... We therefore describe it as feudal duty or as the obedience of a loyal man. For often the name of service signifies the duty of affection which the vassals of an empire owe to their emperor.") [=p.737-8 in the 1574 Cologne edition].

$74 J F 1.4 .5$

75 Ac successu temporis sive id servientium merita sive importunitas procurasset, feuda coeperunt esse vitalia, id est, a domino clienti concedebantur pro tempore vitae, pactionibus interpositis inter dominum et servientem de mutua tutela; et tum vere omnia feuda usus fructus dici poterant. Et haec sunt juris feudalis prima cunabula.

76 Strictly speaking, the timar was close to death by the time Craig wrote the Jus feudale. It had buckled beneath the strain of constant wars of expansion and, with the widespread use of gunpowder, Turkish sipahis, like Western knights, had lapsed into obsolescence.

77 Craig's source on the timariot was Bodin's De republica (supra, n.61) p.190ff. 
dangers of a feudalised economy ${ }^{78}$ - so the comparison would seem apposite enough for a

feudal jurist; yet it is unlikely that Craig's intended readership of Scottish lawyers would

have been any more familiar with the structure of the timar than are their descendants in the

twenty-first century. The fact that Craig has to go into some depth about the workings of the

timar, which includes explaining that it is etymologically derived from the Greek word $\tau \mu \mu$ 向

('honour' or 'honorarium'), ${ }^{79}$ suggests that he anticipated his readers' lack of familiarity.

Indeed, when the English feudist Henry Spelman wrote about this same topic, he dispensed entirely with any reference to Turkish practice, ${ }^{80}$ presumably because it was too obscure a topic to have much illustrative value for a British audience. Not only was the Turkish digression potentially confusing, it also had the effect of muddying the early mediaeval waters with anachronism. Pocock notes the most salient fault with Craig's Turkish analogy: "He seems to think of the Germanic invaders, as of the Turks, as settling their conquered provinces with a strong centralised military class, instantly obedient to the prince's call." 81 One wonders why Craig brought it up at all. He was obviously relying heavily upon Bodin's De republica, which uses the timar as an illustration of lifelong feus and the mutual bonds of affection between vassal and lord ${ }^{82}$ to demonstrate the nature of feus, stating that "what we

78 C. Wickham, The uniqueness of the east, in: Feudalism and non-European societies, eds. T.J. Byres and H. Mukhia, Bristol 1985, p.166-196, at 180; and F. Öztürk, Ottoman and Turkish law, Bloomington 2014, p.7677. A contrary view, common to Marxists and historical materialists is that the "feudal mode of production" describes any economic system where a productive class is dominated by an elite who absorb surplus production through either rent or tax. Unfortunately, much scholarship of this sort has the clear agenda of advancing Marx's theory that the ancient slave economy evolved into the mediaeval feudal economy. In consequence, terms like "feudal" have been redefined repeatedly and twisted away from their original meanings. In Craig's day, the adjective "feudal" was a juristic term and tenure was feudal only if it is governed by principles of the feudal law. For Craig, the holding of land from the Ottoman state would have been equivalent to holding land directly from the Ottoman monarch and, since tenure was dependent upon the timariot providing military service to a superior, it was in accord with feudal legal principles and would ipso facto have been feudal in nature.

79 On the various meanings of the word timar, see Z. Haque, Origin and development of the Ottoman timar system, Islamic Studies, 15 (1976) p.123-134, at 123.

80 Pocock, The ancient constitution (supra, n.30), p.97; by contrast, James Harrington, in his Oceana (1656), compared Turkish timariots to Roman beneficiarii but he did so as part of a much larger historical project than Craig's, one which saw the Ottoman and Roman Empires as analogous manifestations of monarchic absolutism (ibid., p.132-134 and 143).

81 Ibid., p. 82

82 Bodin has been misunderstood by some Marxist scholars who seek to make him much more conscious of the differences between Western feudal practice and the timar than he actually was; for example, see M. Sawer, Marxism and the question of the Asiatic mode of production, The Hague 1977, p.9. 
call a feu, [the Turks] call a timar; and what we call a beneficiary or vassal, they call a timariot." ${ }^{, 3}$ So, if nothing else, this Ottoman digression locates Craig's thought squarely within the web of humanist, and particularly French legal humanist, literature, which may have been the point.

This early period, during which a feu was of lifelong duration and could therefore not be passed to heirs, is described by Craig as the "infancy of feus" and he tells us that it extends down to around the year 650 . The barbarian invaders of the Roman empire, specifically the Franks in Gaul, the Goths in Spain and the Lombards in Italy, "had consolidated the homes they had acquired by the sword and were holding them in leisure and in peace, without any trouble." ${ }^{84}$ It was at this point that Craig discerned the earliest appearance of feudal legal terminology such as feudum ('feu'), vassallus ('vassal') and homagium ('homage'). The first appearance of feudal legal terminology does not necessarily constitute the first appearance of the feudal law, but it suggested the existence of forms of land tenure that were fundamentally different from those of the pre-feudal Roman world. While these words were hugely important for Craig's argumentation, here and elsewhere, ${ }^{85}$ he makes no attempt to define them at this point, because he is interested not in the exact meaning of any particular piece of feudal terminology but in the fact that they are being used at all. However, by describing the land held of another person as a feudum, he is implicitly defining that word; he is assuming that a piece of land and a feu are interchangeable and this is one of the main reasons for Susan Reynolds' sharp criticism of him. ${ }^{86}$ For Craig's historical purposes (which are, it need

83 Bodin, De republica (supra, n.61), p.107, quod nos feudum, ipsi Timar appellant et beneficiaros seu vassallos Timariotas. This is also Craig's source on the supposed Greek etymology. The timar is discussed further on p.190-191, which mentions what Bodin calls the zamoglomos (the devşirme or paidomazoma "blood tax" whereby the children of Christian families were taken as tribute by Ottoman officials) and briefly on p.577. He also mention the timar in passing in the Methodus (supra, n.44), p.413-414).

84 [A]rmis partas sibi sedes stabilierant et sine molestia in otio et pace possidebant.

85 Craig was extremely sensitive to the anachronistic use or misuse of language. Thus, when English historians claimed that the early Scottish kings had been vassals of England and had done homage, Craig dismisses the argument on the basis that feudal concepts like homage did not exist in the British Isles at that time (see L. Dodd, Historical introduction in: Jus feudale tribus libris comprehensum (supra, n.18), p.xiii-lxvi, at xxiii). 86 S. Reynolds, Fiefs and vassals in Scotland: a view from outside, Scottish Historical Review 82 (2003) p.176- 
hardly be said, quite different from those of modern scholars), the purpose of this entire discussion was no more than to establish the earliest point at which feudal language appears and therefore to establish the earliest origin of something that might reasonably be called feudal tenure. Moreover, the process which Craig is describing is a direct consequence of the end of the Roman empire; in a very typically humanistic way, the new feudal society of the middle ages becomes essentially a replacement for the more complex society of ancient Rome. So too the feudal law, even at this embryonic phase, becomes a customary replacement for the displaced Roman civil law.

While no form of hereditary succession to a feu exists at this point in the narrative, Craig nevertheless sees some foreshadowing of hereditary succession within the general culture and milieu of this "infancy of feus". He states that the holders of these feus were called nativi, the Latin ancestor of the English 'native', a word which describes a quality or right that has been imparted by birth. Further, Craig maintains that nativus is a Latin cognate to the Scots law term 'kindly tenant' (a rather superannuated term describing a serf or bondsman) and, again, in this context the Scots adjective 'kindly' describes something imparted by birth. ${ }^{87} \mathrm{He}$ finishes this section by stating that, despite the absence of any form of hereditary succession, "unless a just basis for offence was given or [the tenants] were not fit to serve, it was a harsh thing to remove them from their holdings". ${ }^{88}$ If we take all of this

193, at 177. Recent work has pointed out some of the shortcomings in Reynolds' approach (see Heirbaut, Feudal law (supra, n.19) passim). Certainly as it pertains to Craig, Reynolds has failed to grasp the specifically legal context in which the Jus feudale was produced and the practical function it was intended to serve treating it instead as a theoretical and academic work. This has had a deleterious effect on her interpretation of the text. The present author hopes, in the near future, to explore in detail the problematic treatment Craig has received at the hands of both Susan Reynolds and of Elizabeth Brown who has been similarly scathing in her criticism of Craig and has sought to place on his shoulders responsibility for creating the construct of feudalism (see E.A.R. Brown, The tyranny of a construct: feudalism and historians of medieval Europe, American Historical Review 79 (1974), p.1063-1088, at 1064).

87 See Dictionary of the Scots Language, s.v. kindly.

88 [N]isi justa offensae causa praecesserit et ad serviendum non sufficerent, durum erat a suis possessionibus removere. Craig's interpretation, here as elsewhere, follows similar lines to that of Ganshof who likewise observed that the earliest feudal tenements, though nominally granted for life, were in practice heritable (“des tenures à vie presque toujours et même le plus souvent héréditaires en fait"); see Qu'est-ce que la féodalité? (supra, n.70) p.25. 
together, we can see that there is an implication that hereditary or generational succession to a lifelong feu already existed, not as a legal right but as a privilege or kindness extended by the superior to the vassal's heirs. In his assertion that it was harsh to remove someone from a feu without good reason, we can even see the seeds of feudal morality - the culture of fairness and propriety which, in Craig's mind, defined the relationship between superior and vassal and which were "the training ground for all manners and duties and the only defence against the unjust ambitions". 89

The period between 650 and the reign of Charlemagne is described by Craig as the childhood, or pueritia, of feus and it is then that feus undergo the transition from lifelong tenure to partial heritability whereby the sons of the feudal grantee could inherit their father's feu as a matter of right. "Thus a feu, which had heretofore been no more than a usufruct, was extended to the sons or to the one of them whom the lord considered most suitable for his service." 90 It seems significant that Craig would make this point, that the earliest iterations of feudal tenure were, in practical terms, indistinguishable from usufruct. ${ }^{91}$ During the middle ages, feudal lawyers had wrestled with the question of how and if ownership of the feu was divided between superior and vassal; Pilius, a jurist from the law school of Bologna whose floruit was in the late twelfth century, developed the idea of a divided ownership in which the vassal received dominium utile and the superior retained dominium directum; ${ }^{92}$ when Accursius wrote his Gloss, he incorporated this idea and, as a consequence, was often thought of as its originator. ${ }^{93}$ In the sixteenth century, a group of legal humanists emerged to whom the idea of divided dominium was repugnant because it was not found in the civil law

89 Epistola nuncupatoria, in Craig, Jus feudale (supra, n.18), p.lxxiv (Latin) and lxxv (English).

90 Itaque feudum quod prius tantummodo usus fructus erat, etiam ad filios continuabatur, aut ad eorum aliquem quem dominus servitio suo aptissimum designabat.

91 Cf. Pocock, The ancient constitution (supra, n.30), p.81

92 See R. Feenstra, Les origines du dominium utile chez les glossateurs, in: Fata iuris Romani, ed. R. Feenstra, Leiden 1974, p.215-259, passim.

93 Gretton, Feudal system (supra, n.23), para. 49, n.2; see also T. Rüfner, The Roman concept of ownership and the medieval doctrine of dominium utile, in: Creation of the ius commune: From casus to regula, eds. J.W. Cairns and P.J. du Plessis, Edinburgh 2010, p.127-142, at 130-131. 
and they advanced instead the idea that a feu was no more than a usufruct. In the ninth title of Book 1 of the Jus feudale, Craig explains that "Cujas, Schöner and the modern commentators" maintained that "the word [feudum] refers...only to the usufruct of the property" with undivided dominium remaining with the superior, ${ }^{94}$ therefore a feu could not grant ownership of any kind to a vassal, but merely a right of use over property owned by someone else. These scholars were advancing a Romanising interpretation which treated feudal tenure as either a derivation of or as functionally identical to Roman practice and which saw deviation from Roman legal norms as something abhorrent; at least for some of them, part of their motivation was the humanist impulse to treat the mediaeval as intrinsically inferior to the ancient. But, in any case, what the mediaeval glossators had called dominium utile was, in the eyes of Cujas and his colleagues, merely a burden on the superior's right of ownership. Craig tells us that, "Of the modern writers whom I have read, only Hotman supports the division of ownership into directum and $u t i l e " ;{ }^{95}$ while this is true, the argument of Cujas and his fellows never posed a serious practical challenge to the prevailing theory of duplex dominium. Craig followed Hotman in coming down firmly in support of the traditional view that a feu conferred one form of ownership on the grantee while the granter retained another form of ownership and that, therefore, usufruct played no part in feudal law or tenure. It is possible to look at later Scots practice of duplex dominium and assume that it became the law of Scotland because Craig, and later Stair, sanctified it; 96 thus Baird Smith remarked that " $[\mathrm{t}]$ he adoption...of Hotman's two dominia was a decision of capital importance in Scottish legal theory". ${ }^{97}$ It is, however, more likely that Craig's endorsement of the mediaeval construct of duplex dominium was the articulation of then-current practice in Scotland. It is unlikely that the theory of feudal usufruct had ever been widely accepted by

\footnotetext{
$94 J F 1.9 .4$

95 JF 1.9.11: Solus ex recentioribus quos legi, Hottomannus hanc distinctionem dominii in directum et utile probat.

96 Gretton, Feudal system (supra, n.23), para. 51; cf. MacQueen, Common law (supra, n.17), p.22.

97 Baird Smith, François Hotman (supra, n.32), p.351
} 
Scots lawyers and still less likely that it found its way into the courts. Craig, despite his humanist impulses and appreciation for classical Roman culture, rejected the simplistic idea that the ancient had always to be preferred to the mediaeval and in this he reveals something about the complexity of his legal worldview.

Craig addressed the usufruct debate directly and substantively in his ninth title, ${ }^{98}$ but, for present purposes, it will be sufficient if we merely acknowledge that he rejected the notion that a feu was a usufruct. Yet that requires us to explain his meaning when he said that the earliest feus imparted only usufruct. Since he cannot have meant that a feu was literally ususfructus, in the Roman legal sense, nor that the feu in any way derived from the Roman law, he must have meant that a feu in the 'childhood of feus' was functionally or practically identical to the usufruct. Indeed, when he discusses the topic in his ninth title, he explains that feus and usufructs share certain similarities, ${ }^{99}$ but are nevertheless distinct legal phenomena. ${ }^{100}$ By the same token, when Prof. Gretton described the earliest manifestation of a feu as "in origin a species of usufruct", ${ }^{101}$ he was not implying that the feu was a form, evolution or development of the classical Roman ususfructus; he meant simply that Roman usufruct and early feus both imparted a right to use land which belonged to another party who retained ownership. In part, Craig's insistence that a feu was not truly a usufruct derived from his understanding of the differences between feudal and civil law and attendant refusal "to accept the application of of legal categories derived from Roman law to feudal conceptions". ${ }^{102}$ While Craig was conscious that the feudal law had come to form a kind of

98 J.W. Cairns, Craig, Cujas and the definition of feudum: Is a feu a usufruct? in: Law, lawyers and humanism, ed. J.W. Cairns, Oxford 2015, p.401-412, has a full treatment of Craig's argumentation on the topic.

99 JF 1.9.10, [P] raeterea in multis feudum cum usufructu convenire et ejusdem esse naturae pene cum feudo, cum neque deteriorem feudi conditionem feudatarius facere possit, neque usufructuarius proprietatis. ("[I]n many respects a feu accords with a usufruct, which is practically of the same nature as a feu, because just as a feudatory cannot worsen the state of his feu, neither can a usufructuary worsen the state of his property.") 100 So, for example, if a feu were truly a usufruct, then neither curiality nor subinfeudation would be possible as it would create two usufructs over the same feu; see $J F$ 1.9.11.

101 Gretton, Feudal system (supra, n.23), para. 43

102 J.C. Gardner, French and Dutch influences, in: An introductory survey of the sources and literature of Scots law [=Stair Society, vol. 1], Edinburgh 1936, p.226-234, at 231 
literary and theoretical appendix to mediaeval reception of the civil law, ${ }^{103}$ he nevertheless distinguished between them.

In the next section of the fourth title, Craig continues the story of feudal tenure's evolution telling us that during the 'childhood of feus' the vassal's lifelong rights were extended so that sons could inherit their father's feu. ${ }^{104}$ The nature of succession varied from place to place - in some places, it was per capita, in others by nomination or, in places such as Britain, by primogeniture. Inheritance was limited to one generation because "[i]n those days, where a feu had been given to a man and his sons, grandsons were excluded from succession". ${ }^{105}$ Craig feels that this oddity merits explanation because, as he says, "in law grandsons are very often encompassed by the term 'sons'."106 The reason for this seeming discrepancy is that feudal grants were held to be stricti juris as they are, by nature, privileges. ${ }^{107}$ Accordingly, if a granter provides only for the grantee and his sons, then it cannot legitimately be extended to grandsons; had the granter wished to provide for the grantee's grandsons, then "he could have expressed it in the grant of the feu."108 This is Craig's first articulation of a supremely important principle of feudal law: namely, that the intent of the granter must always be taken into account when dealing with the fate of a feu. This, he explains, is quite different from the common law of feus, where a disposition in favour of a man and his sons extends to grandsons without limit, but it is analogous to the situation in the civil law where a privilege granted to a man and his sons is limited strictly to that man and his sons and no-one else. This was, Craig goes on to say, a highly topical point

103 Cf. JF 1.2.15 where the feudal law is described as "practically part of the civil law". See also Heirbaut, Feudal law (supra, n.19) p.537-538.

$104 J F 1.4 .7$

105 Nepotes autem in feudo alicui et ejus filiis concesso eis temporibus a successione arcebantur.

106 [I] jure filiorum nomine nepotes saepissime contineantur. The print editions of Jus feudale all cite Digest 50.16 .201 as a source for this assertion.

107 Bartolus makes the same point: [F]eudum esse contractum consuetudinarium et stricti juris et esse stricte interpretandum. ("A feu is a customary contract stricti juris and must be interpreted strictly.") Commentaria in primam digesti veteris partem (Basel, 1589), p.276

108 [Q]uibus si voluisset provisum id in feudi concessione expressisset 
since there were those who, as a means of thwarting the Stuart succession to the English throne, sought to deny that a privilege granted to the king's son also extended to his grandson. He finishes this section by reiterating that the childhood of feus lasted from the year 650 until the accession of Charlemagne (which Craig dates to 800) and by defining a feudum within this period as "merely a usufruct which had been granted to some servant or vassal and his first heir or heirs of the first degree."109 The true (fully heritable) feu only emerged with the "adolescence of feudalism", or adolescentia feudi, which Craig assigns to the time of the Emperor Conrad's expedition to Rome. ${ }^{110}$

\section{The adolescence of the feudal law}

Drawing heavily upon the Libri feudorum, ${ }^{111}$ Craig tells us that while mustering for their campaign in Italy, Conrad's vassals promised to perform deeds of great courage and were rewarded with a widening of the feudal law so that, for the first time, the inheritance of a feu was extended to grandsons and collaterals without limit. Craig makes clear that this was something specifically sought by the vassals; it was not an idea that originated with Conrad, although he had no compunction about granting the request because he thought it would inspire greater loyalty and bravery among his men. Characteristically, Craig compares the mediaeval practice with contemporary Scotland, saying "we see much the same thing happen in our country when kings who are either engaged in conflict or about to be are accustomed to ready the line of battle by promising their kin wards, reliefs and even ecclesiastical

$109[$ [E] tempore feudum tantum erat usus fructus alicui servienti sive vasallo et primo ejus heredi sive primi gradus heredibus concessus. In fact, texts and law codes from this period show no traces of feudal practice; see Gretton, Feudal system (supra, n.23), para. 43 on the conveyancing text Marculfi formulae (660) and the Edicta of the Lombard kings Rothair (issued 643) and Liutprand (issued 713-735).

110 JF 1.4.8. The Libri feudorum does not specify which Emperor Conrad is under discussion; consequently, it became a topic of debate among humanists. The controversial word "feudalism" is used here as a shorthand for the broader system of law and tenure; the literal English translation of the Latin text ("the adolescence of the feu") would not necessarily convey Craig's meaning fully.

$111 L F 1.1$ 
benefices". ${ }^{112}$ This is, he says, "a commendable enough arrangement...because the morale of the soldiers is encouraged and their zeal is repaid, as they know that no property will be lost to those about to die for their country". ${ }^{113}$ This comment is more significant than it might at first appear, because Craig is explicitly treating military service not as something to which a monarch is absolutely entitled but as part of a quid pro quo whereby those who risk their lives are to be compensated and those who lose their lives are to be assured that their family will not be impoverished. Craig's feudal sociology depended entirely upon the mutual bonds of affection and obligation created by the superior's generosity and the vassal's gratitude. As he envisioned it, the superior was not some oppressive figure who lorded it over a wretched underling, ${ }^{114}$ rather, both were parties to a specific form of contract that created and depended upon obligations of mutual protection, counsel and benevolence. ${ }^{115}$ It is important that Craig did not see this extension of feudal inheritance as in any meaningful way weakening royal power; indeed, the widening of inheritance was implicitly limited because only a vassal who had accompanied the emperor to Italy could benefit.

Following these observations on the widening of feudal inheritance, Craig attempts to fix the feudal chronology by identifying the Conrad in question, something not specified by the Libri feudorum. By the time the Jus feudale was written, the Holy Roman Empire had had

112 [Q] uemadmodum et apud nos fieri videmus, cum in procinctu acies stant, ut reges eorum qui in ea pugna sive ad pugnam expeditione morerentur, wardas, relevia et beneficia etiam ecclesiastica propinquioribus promittere soleant.

113 Laudabile sane institutum, nempe ut militum animi confirmentur et acriores reddantur, cum sciant morituris pro patria nihil de bonis decessurum.

114 In Anglophone literature, there has long been a tendency to treat the relationship created by feudal tenure as innately oppressive (cf. Dodd, Historical introduction (supra, n.85), p.xl-xli). Indeed, the very first appearance of the phrase "feudal system" originated in Adam Smith's Wealth of Nations (1776) and was used to describe an economic system guided by coercion rather than market forces and, with this meaning, it was later taken up by Marxists who still use it with this sense (R. Abels, The historiography of a construct: "feudalism" and the medieval historian, History Compass, 7 (2009), p.1008-1031, at 1011).

$115 \mathrm{Cf}$. JF 2.5.8, where Craig discusses these qualities in respect of manrent, although, as Dr. Wormald noted, it was never clear whether Craig saw manrent as a feudal arrangement in its own right or whether he thought it was a non-feudal exemplification of feudal ideals (J.M. Wormald, Lords and men in Scotland: bonds of manrent, 1442-1603, Edinburgh 1985, p.12-13). See also J. Goodare, Nobility and the absolutist state in Scotland, 1584-1638, History, 78 (1993) p.161-182 at 163-164, where manrent is described as creating "a kind of artificial kin relationship". I am grateful to Prof. H.L. MacQueen for pointing out that manrent could be used as a synonym for homage in the later middle ages, though not limited to that meaning. 
four emperors named Conrad, ${ }^{116}$ with the first reigning from 911 to 918 and the second between 1027 and 1039. Craig reasons that the emperor in question can only have been Conrad II because neither Conrad I nor Conrad III were ever said to have made an expedition to Italy, while Conrad IV lived long after the composition of the Libri feudorum and therefore could not be its subject. ${ }^{117}$ This is an interesting example of the humanist method for establishing chronology, but it is not Craig's own work. It was actually Dumoulin who first identified the emperor mentioned in the Libri feudorum with Conrad II. ${ }^{118}$ Craig is merely following him.

In a larger sense, Craig does not seem to have been entirely comfortable with some of the complexities of humanist periodisation, which may be a reflection of his legal background and focus. He clearly felt that neat divisions between historical periods were a necessary part of humanistic historiography and thus he divides the life cycle of feudal law and tenure into infancy, adolescence, adulthood and senescence; yet he did not execute this process of periodisation quite as precisely as some other humanist writers. So, Craig tells us that the childhood of feus lasted from 650 until Charlemagne's reign (1.4.7) and next tells us that the adolescence of the feudal law began with Conrad II (1.4.8). However in that same section he also says that the adolescence began with Charlemagne and ended with Conrad, ${ }^{119}$ with the implication that feudal tenure attained maturity when Conrad extended feus to grandsons and collaterals. Later still, he says that feudal tenure did not reach adulthood until the Capets made hereditary succession perpetual in France (1.4.11). The likely reason for this inconsistency is simply that Craig's feudal life cycle, although a novel metaphor, did not

\footnotetext{
116 Strictly, Conrad I was not emperor but merely King of East Francia; it is nevertheless common to treat and number him as though he had been the Holy Roman Emperor.

117 Cf. Craig, Jus feudale (supra, n.18), p.103, n.46

118 Kelley, De origine feudorum (supra, n.1), p.211

119 Et huic adolescentiae, si textus verba sequamur, ea tempora assignamus quae a Carolo Magno ad Conradi tempora intercesserant ("If we follow the words of the text, we must designate the period between Charlemagne and Conrad II as the adolescence of the feudal law.").
} 
exactly fit the evolution of feudal practice as he saw it and, as a result, he was not entirely clear on where (or, rather, when) to draw the dividing lines between different feudal periods. This is not a particularly important issue for Craig's broader argumentation and it would be wrong to dwell on it, but it is interesting as an illustration some of his historiographical limitations, some of the places where his product was not quite as polished as he might have wished. In broader historiographical, and therefore literary, terms, it shows the discrepancies that arose in humanistic historical works precisely because authors were so conscious of the different chronological periods into which history had, for epistemological and heuristic reasons, been divided and therefore so eager to demonstrate their mastery of history and historical writing through the utilisation of their own expressions of periodisation.

The description of the initial impetus for the heritability of feus - whereby a monarch about to depart for a campaign in Italy arranges matters of that his vassals will be succeeded by their sons - is extremely reminiscent of the Capitulary of Quierzy promulgated by Charles the Bald in similar circumstances in $877 .{ }^{120}$ Given that Quierzy seems to have been the first instance in which the Carolingian monarchs determined that a deceased vassal's benefice should pass to his son as a matter of right, it would appear to be an important and useful matter for Craig's general argumentation and we might have expected him to mention it. The fact that he does not is most convincingly explained by his being unaware of its existence. Indeed, Craig's general grasp of Carolingian history is never entirely secure. ${ }^{121}$ But, notwithstanding that Craig was writing about historical events, he was not primarily an historian. He was essentially a lawyer writing about historical matters in order to illuminate contemporary law and practice. This left certain gaps in his work, some relating to sources and others, such as the issues with humanist periodisation, more methodological in nature.

120 On the Capitulary of Quierzy, see Ganshof, Qu'est-ce que la féodalité? (supra, n.70) p.67.

121 See, for example, $J F$ 1.7.5 where he appears to confuse the Frankish king Charles the Simple with the Carolingian emperor Charles the Fat. 
Moving on, Craig reiterates what he has already said and explains that Conrad's widening of feudal inheritance applied only to ancestral feus (that is, to feus which one had inherited from a progenitor) not to novel, or newly-created, feus. ${ }^{122}$ An ancestral feu belonging to a vassal who had accompanied Conrad II to Italy could be inherited by the vassal's brothers, not just by his sons, but novel feus were governed strictly by the terms of the feudal grant, meaning that no collateral inheritance could occur unless the superior had made specific reference when disponing. So already, in the eleventh century, Craig perceived the emergence of distinct, though not wholly divergent, feudal traditions which had created different expressions of feudal tenure with different privileges, different obligations and therefore fundamentally different expressions of the vassal-superior relationship. It was following Conrad's reign that vassals began to treat their feus as their own personal property rather than as land belonging to another; they farmed the land and built upon it "largely untroubled by the will of their superiors, so long as they executed their agreed duties". ${ }^{123}$ Once more, this seeming change in attitude is not presented as a weakening of royal power; indeed, by articulating that the vassal's free use of the property was contingent upon the fulfilment of feudal obligations, we can infer that Craig construed this as the development, not the subversion, of the traditional feudal relationship - and he does, in fact, note that the feudal law in this period "matured remarkably". ${ }^{124}$ It is important that we understand the full linguistic implications here. The Latin verb Craig uses here - adolescere - is, of course, the root of adolescentia which can be translated as "maturing" or, as the present author has done, as "adolescence". These word choices give a strong sense of development or evolution, not degradation or decay. Following Craig's metaphor of the feudal life cycle, this is merely a single step in the process of juristic development by which customary practice crystallises

122 On the division between ancestral and novel feus, see $J F 1.10 .13$.

123 [S] ecuri pene de dominorum voluntate, modo servitia conventa praestarent.

124 [Q]uidem tempore jus feudorum mirum in modum adoleverat ("[The adolescence of feudalism] was a time in which the law of feus had matured remarkably."). 
into its archetypal expression.

At this point, Craig introduces the alternate hypothesis that the feudal law has a Roman origin. This is a topic to which he will return in the succeeding fifth title, so it is not immediately clear why he chose to raise the point here as well. Regardless, he explains that the Roman emperor Alexander Severus (r. 222-35) had granted lands on the frontiers to soldiers "averring that they would be more attentive in their military service if they were also defending their own property". ${ }^{125}$ From this, "Italians" concluded that there existed "some kind of military feu among the Romans, which was descendible to heirs". ${ }^{126}$ Hotman makes a similar point in his Disputatio and it is certain that Craig had read it. ${ }^{127}$ However, where Hotman mentions in passing that his source is the Roman writer Lampridius, Craig would appear to have gone to directly to the primary source because his Latin is so close to that of Lampridius that it is practically a quotation. Thus, where Craig says asserens eos attentius militaturos si et sua defenderent ("....averring that they would be more attentive in their military service if they were also defending their own property"), Lampridius has dicens attentius eos militaturos si etiam sua rura defenderent (“...saying that they would be more attentive in their military service if they were, in addition, defending their own fields"). The similarity is too pronounced to be a coincidence, so Craig either checked Hotman's account against a text of Lampridius or, at the very least, utilised another source which contained a direct quotation. Whichever it may be, we are seeing another instance of Craig's critical historical method. Even where he is heavily dependent upon a source, he is rarely uncritical. The main exception to this rule is with Greek language texts where, both due to limited linguistic faculty and even more limited availability of Greek editions, he was forced into reliance on the reports and quotations of others. ${ }^{128}$ It would very easy to look at Craig's

125 ...asserens eos attentius militaturos si et sua defenderent.

126 Hinc Itali colligunt et apud Romanos feuda quaedam fuisse militaria, quae ad heredes descenderent.

127 Hotman, Disputatio de jure feudali (supra, n.30), p.15

128 Cf. Dodd, Craig's aetiology (supra, n.7), p.129 and 175-177 
reading of European texts and see him as a copyist, particularly since he seems to have been bound and determined to present Scots feudal law in terms of the European ius commune, ${ }^{129}$ but, for all that he articulates and, indeed, relies upon the opinions of other jurists and historians, his treatment of them is discriminating and critical. Whatever his sources, classical or contemporary, the analytical work was largely his own and it is impressive for its originality and historiographical complexity.

Among the other points in this section that deserve consideration, it is significant that Craig refers to those who advance the Romanist thesis of feudal origins as "Italians". In fact, many of the most important Romanists were not Italian at all, so he is presumably using the term to describe scholars who utilised the mos italicus as opposed to those who use the mos gallicus (amongst whom would be Craig himself, notwithstanding his use of and reliance on many famous mediaeval writers on feudal law); so the point would be to contrast the growing historical awareness of humanists with these "Italians" who lumped the Holy Roman Empire together with ancient Rome and Byzantium as an undifferentiated whole. Indeed, since Craig perceived law as having passed from the ancient Israelites, through Greece and Rome, to France whence it was ultimately brought to Scotland, ${ }^{130}$ it was necessary to demonstrate that this process of translatio studii had not involved a weakening of the law's innate truth. Craig is therefore driven to assert that the legal learning derived from France (the mos gallicus or what we now call legal humanism) is methodologically superior to the learning of the mediaeval Italian jurists. ${ }^{131}$

129 Cairns, Breve testatum (supra, n.32), p.317, n.36; MacQueen, Tears of a legal historian (supra. n.17), p.24 130 Ford, Law and opinion (supra, n.9), p.211-216 and 222-223; Dodd, Craig's aetiology (supra, n.7), p.129 and 175-177. This is not, however, to suggest that Craig ignored or disdained the mediaeval sources on feudal law. It was clearly important to Craig to show the ways in which mediaeval authors on the feudal law could and should be used to explicate the current practice and historical development of feudal law and tenure. Bartolus and Baldus are cited throughout, but the later writer Alvarotto, who originated the idea that there existed a common jus feudale from which all later feudal custom derived, is also treated as an authoritative source (e.g. JF 1.12.26-27).

131 These observations are owed entirely to Prof. J. D. Ford, to whom the present author is deeply grateful. 
It is, in any case, peculiar that Craig should focus so heavily on Lampridius' account when most Romanist scholars, such as Cujas, saw the Roman origins of feudal tenure as lying within the Corpus iuris civilis. There is no immediate explanation of this latter point, but one might conjecture that Craig simply found the text interesting. From a modern perspective, the most important point here is that, whereas jurists advancing a Roman origin of feudal law insisted upon the early existence of an articulate form of feudal tenure, Craig envisioned an extended process of juristic evolution, from ancient tribal society to a developed system of law and tenure. This underlines the sophistication of his historical analysis.

\section{The feudal law reaches manhood}

The maturation of the feudal law, as Craig construed it, was the process by which feudal tenure became hereditary as a matter of right. ${ }^{132}$ Hereditary inheritance of feus was first attested under Charlemagne, who granted land to soldiers which would then pass to their sons, whereas, before this point, feudal tenure had only been lifelong. ${ }^{133}$ From here, Craig's account takes an interesting and important turn as he explains that Lothair I left an imperial constitution on feudal inheritance employing almost exactly the same words as the constitution of Conrad Salian. On the basis of this, Hotman, who, as we have said, was Craig's favourite source, concluded that it was Lothair, not Conrad, who first instituted hereditary possession of feus. ${ }^{134}$ Craig's divergence from Hotman's account is given in very polite terms and he concedes that Hotman "presented many good reasons" for thinking as he did, but nevertheless rejects Hotman's thesis entirely and explains in detail why it is incorrect. He says that while feus did pass from vassals to their children as early as the reign

132 Cf. Kelley, De origine feudorum (supra, n.1), p.219: "[H]ereditability...was, as both jurists and historians realized, the final stage in the formation of feudal law."

$133 J F 1.4 .10$

134 Hotman, Disputatio de jure feudali (supra, n.30), p.231 
of Charlemagne, this was a privilege proceeding from the kindness of the superior and not a matter of right. The privilege of hereditary succession to a feu had become common in Lothair's day, but it was not universal, it was not a legal right and therefore it was not feudal law. Hotman's mistake, as Craig saw it, was in construing specific instances of generosity as amounting to a fixed legal rule. However, beyond the specific point about rights of succession, this matter demonstrates that, even when dealing with a writer he respected and a source he trusted, Thomas Craig was more than capable of striking an independent line. He was neither cowed by Hotman's sterling reputation nor obligated by loyalty to his source. ${ }^{135}$ This is true his handling of other sources as well. The mere fact that Craig used and respected an author can never be an indication that his thought was identical to that of the author in question. Thus we must be wary of trying to discern Craig's unarticulated opinions by excavating them from the sources he used.

As Craig saw it, genuine hereditary succession to a feu occurred only after the end of the Carolingian dynasty, when the Capets took the Frankish throne. ${ }^{136}$ Wishing to secure the loyalty of the magnates, the first two Capet kings, Hugh I and Robert II, made succession to feus hereditary. The effect of this was to turn "duchies, counties and baronies" that had heretofore been lifelong royal appointments into the perpetual property of a single family; ${ }^{137}$ vassals, in Craig's own words, "now enjoyed the land by right and not by either precarious tenure or the whim of another". ${ }^{138}$

Finally feudal tenure had reached the stage that Craig considers manhood, by which he means that the privilege of hereditary feudal inheritance had finally crystallised into heritable

135 By the same token, at $J F 2.11 .10$, Craig seems taken aback by the vituperativeness of Hotman's criticism of Obert and Gerardus, the authors of the Libri feudorum, and expresses his belief that Hotman, though "a gentleman of the soundest judgment" (vir sane magni judicii), had let himself "get carried away beyond what is reasonable by the hatred which he openly displays for the law of feus" (odio, quod in jus feudorum aperte Hottomannus profitetur, paulo eum altius, quam par erat, evictum constat). The printed editions of the Jus feudale have evectum but the present author feels that evictum makes more sense in context.

$136 J F 1.4 .11$

137 Cf. Ganshof, Qu'est-ce que la féodalité? (supra, n.70) p.81.

$138[N]$ on precario, neque ex alieno arbitrio, sed jure suo utebantur. 
tenure as a right backed by a framework of legally enforceable custom. Pocock criticised Craig for a tendency to see "feudalism" as a centralising force instead of as the decay of royal power, ${ }^{139}$ what we can see here is that Craig's understanding of the royal-noble power dynamic was much more sophisticated and more contextually aware than he has been given credit for. In an historical sense, he appears to have been fully aware that the transition to a hereditary aristocracy was deleterious for Frankish royal power and he is clear that it came about not organically but as a conscious effort on the part of the Capets to secure their hold on a throne to which they had only a tenuous claim. As Craig saw it, the growth and development of feudal practice, at least in tenth century France, was not about weakening the power of monarchy so much as it was about strengthening the political position of the first two kings of a new and potentially vulnerable dynasty. In other words, monarchic authority over the longer term was traded off for immediate political security.

The Capets allowed feudal inheritance in the first degree - that is, father to son - but "the transition from like to like is easy" and so "the passage of time arranged it so that not only brothers but also cousins in the fourth degree could succeed one another". ${ }^{140}$ In other words, having let the genie out of the bottle by allowing feudal inheritance from father to son, it proved impossible to stop the widening of inheritance to encompass other relatives. In time, inheritance was extended to any descendent of the feu's initial grantee, regardless of degree of consanguinity to the present holder. In the next section, Craig explains the means for calculating degrees of kinship, noting particularly that the canon and civil law use different methods and that while feudal law generally follows the civil law, Scottish practice follows the canon. The title concludes with the following remark: "This period can be called the manhood of feudalism, because the feudal law had acquired these powers for itself to the

139 Pocock, The ancient constitution (supra, n.30), p.87

$140 \mathrm{JF}$ 1.4.12: [C] um facilis a simili in simile sit transitus, fecit progressus temporis ut non solum fratres sed etiam patrueles qui in quarto gradu essent ad invicem sibi et mutuo succederent. 
extent that, in matters of succession, the feudal law alone was taken into account; in

judgments, lawyers followed only the feudal law, ignoring or disregarding the civil or canon law, as I said above. Thus the law of feus was born, raised and finally strengthened and completed."141 The manhood - or aetas virilis - of the feudal law was the point at which it finally became a unified juristic expression that was accepted by lawyers and utilised in practice.

\section{Competing theories}

In the fourth title of Book 1, Craig laid out his basic narrative of European feudal history from inception to full maturity. He follows this in the fifth title, the shortest in the entire Jus feudale, by setting out, usually without any real editorial comment, the main competing theories on the origins of feudal law and tenure. The fifth title opens with a condemnation of the recentiores - the more recent legal authors - for their rejection of the actual authors of the feudal law and their determination to find some other genesis; as he mentions elsewhere, foremost among these recentiores is Cujas. ${ }^{142}$ All legal humanists, recentiores and antiquiores alike, had noted that the Libri feudorum describes the feudal law as antiquissimum ('most ancient'). ${ }^{143}$ If the law was, indeed, most ancient, then it could not have arisen with the Emperor Conrad, who instituted feudal succession a mere 150 years before the law was set down in writing by Obert and Gerardus. Where, then, was its actual, ancient origin? As we have seen, Craig followed those who found an origin among the German tribes described by Tacitus, with the germ of feudal practice being transplanted to the

\footnotetext{
141 JF 1.4.13: Et haec virilis feudi aetas dici potest, cum eas sibi vires jus feudorum acquisivisset, ut in successionibus solum attenderetur; in judiciis illud solum jurisprudentes sequerentur, neglecto sive praeterito (ut antea dixi) tam jure civili quam pontificio. Et sic feudorum jus natum et educatum et tandem confirmatum et absolutum est.

142 JF 1.8.10; cf. J.W. Cairns, Ius civile in Scotland, ca. 1600', Roman Legal Tradition, 2 (2004), p.136-170, at 151 .

143 LF 1.1.1: Antiquissimo enim tempore sic erat in dominorum potestate connexum.
} 
ruins of the Roman empire by invading barbarians. The recentiores advanced a great many other possible origins for feudal law and tenure, many, though not all, of which involved feudal tenure deriving in one way or another from the law and practice of imperial Rome. The recentiores often had their own political reasons for the positions they adopted - so, for example, some French feudists were reluctant to accept an origin which might imply that their own country's feudal law was derived in any way from constitutions of the German emperor, lest this might imply something unfortunate about French royal sovereignty ${ }^{144}$ but, from Craig's extremely practical perspective, such issues were abstractions of no direct import. Notwithstanding his French legal education, he existed at a distant remove from these kinds of issues. He had the luxury of focusing on the plausibility of any given proposition rather than on its political or cultural implications. He was, however, aware that there existed regional, national and even political biases in favour of specific accounts of the origins of feudal law and tenure.

Italian scholars looked for the origins of the feudal law in the Roman tradition of clientage. ${ }^{145}$ As we noted earlier, most of those advancing a Roman origin narrative were not actually Italian by nationality, so it is likely that Craig is describing these scholars as practitioners of the mos italicus and thereby trying to contrast the nuanced French humanist understanding of history and periodisation with the older tendency to treat history as an undifferentiated whole. Craig then cites one of these "Italians", the French humanist Budé whose 1508 commentary on the Digest first articulated the possibility that the feudal law could have evolved from the Roman custom of clientage. Those who followed this position saw the Roman patron as analogous to the feudal superior and the client to the vassal; what Romans called faith (fides) evolved into fealty (fidelitas), with

\footnotetext{
144 Kelley, De origine feudorum (supra, n.1), p.214-215. The fact that the Libri feudorum contained so much legislation from successive emperors is a partial explanation for the text's importance in Germany; see Heirbaut, Feudal law (supra, n.19), p.537-538. $145 J F 1.5 .2$
} 
both feudal tenure and clientage marked by mutual honour, aid and respect. Others, Craig explains, preferred the idea that feudal tenure began with the Roman imperial policy of granting lands taken from conquered foes to military veterans who had completed their service. ${ }^{146}$ This is the longest section of the fifth title and bears closer inspection, if only because Craig himself seems to have found it interesting. He illustrates the Romanist argument with examples taken from classical Latin literature; thus, he recounts a story in which Octavius (the future Augustus), after winning the civil war against Mark Antony and Lepidus, punished the city of Cremona for disloyalty by granting some of its lands to his veterans. When these proved insufficient, he annexed land from Mantua, which unfortunately included the ancestral estate of the Roman poet Vergil, ${ }^{147}$ who then, after being chased off at sword point by the centurion to whom the farm had been given, was compelled to go to Rome and ask Octavius directly for relief. This is a colourful story and one can understand why Craig might enjoy telling it, but he introduces further examples from Horace and Lucan in which Roman soldiers were or were not given lands to which they felt they had a right on the basis of their military service. ${ }^{148}$ As he did in the previous title, ${ }^{149}$ Craig brings up the example of Alexander Severus, the Roman emperor who settled soldiers on the frontier, and draws the comparison between this and the Turkish timar. However, Craig draws a very important distinction between Roman and feudal practice: the Romans gave land to soldiers who had completed their military service ("Only veterans founded colonies in this way, men who had grown old either advancing or defending the honour of the Senate"). ${ }^{150}$ The obvious implication - that feus were given to fighting men in return for their ongoing loyalty, not for historical service - is not something upon which Craig dwells here, though he does expand on this point a few pages

146 JF 1.5 .3

147 Vergil, Eclogae, 9.28

148 Horace, Sermones, 2.6.55-6; Lucan, Pharsalia, 1.343-6

149 JF 1.4 .9

150 Soli tamen antea veterani deducebantur qui pro dignitate senatus aut promovenda aut conservanda consenuerant. 
later. $^{151}$

In concluding this section, Craig comments that "[t]here are many who think it is relevant that Romans were accustomed to give benefices as a gift (that is, lands, cities and even kingdoms captured from enemies) to those kings whom they had accepted in friendship." ${ }^{152}$ He illustrates this by reference to stories in which Roman allies had been given land as a reward for loyalty: first, the Numidian king Massinissa who fought for Rome against Carthage and received extra territory in return; then the Aedui tribe in Gaul who were allied with Julius Caesar and received in return the territory of the neighbouring Hedui; and Tasgetius, a magnate of the Carnutes who, with Caesar's help, deposed his rivals and became king. These accounts, though, are only superficially akin to feudal practice; the greatest similarity to the European feudal archetype, he says, is to be found in a speech to the Roman senate by Adherbal, grandson of Massinissa, reported in Sallust's book on the Jugurthine War, ${ }^{153}$ in which the Numidian king acknowledged that he ruled not in his own right but as a steward on behalf of Rome, something which Craig saw as akin to the duplex dominium of classical feudal theory. All of this material, including the speech quoted from Sallust, has been taken from Hotman's feudal commentary. ${ }^{154}$ This is not surprising, given the deep respect that Craig felt for Hotman's scholarship, but it does blur the boundary between Craig's own original thought and that of Hotman; at worst, it could lead one to suspect that Craig is no more than a vehicle for expressing his source's opinion. What must be recognised here, and throughout his treatment of feudal history, is that Craig was not the first writer to deal with the topics under discussion. Whatever the specific purpose he envisioned for the Jus feudale in its Scottish context, the book was, in a wider sense, the means by which Craig

151 At $J F$ 1.5.9.

152 JF 1.5.3: Plerisque huc pertinere videtur, quod Romani regibus, quos in amicitiam receperant, beneficia, id est, agros, urbes, etiam regna ex hostibus capta, dono dare solebant.

153 Sallust, Bellum Iugurthinum, 14

154 Hotman, Disputatio de jure feudali (supra, n.30), p.9-10 
dipped his toe into a series of long-running scholarly disputes - some of which had begun decades before Craig was even born - and the entire fifth title, amounting as it does to the summary of most of the existing theories for the origins of feudal law and tenure, is the firmest possible evidence of this fact. His dependence on Hotman signified not a lack of originality but a simple need to summarise accurately and succinctly the accretion of humanist learning on the topic.

Moving on, Craig next deals with the theory of a Celtic or Gallic origin, the main evidence for which is a remark from Caesar's account of the conquest of Gaul describing the soldurii, a select group of warriors who pledged themselves to a chieftain and, in return, received their living from him. ${ }^{155}$ This was the theory advanced by François Connan, though it never gained much traction. ${ }^{156}$ Here, too, Craig is borrowing from Hotman who, just a few pages after his discussion of the Numidian kings, discusses the theory of a Gallic or RomanoGallic origin for feudal tenure and deploys precisely the same quotation from Caesar that Craig uses; they differ only in that Hotman specifically attributes the Celtic theory to the "most learned gentleman" François Connan, saying that he "argues that the custom of feudalism spread from the Gauls to the Germans, Spanish, Italians and the other peoples of Europe", ${ }^{157}$ whereas Craig does not mention Connan by name. ${ }^{158}$ This is probably most easily explained if we consider that Connan's theory was not a particularly important one, either in Craig's day or subsequently, so it was enough to acknowledge its existence and move on; by

155 JF 1.5.4, citing Caesar, De bello Gallico, 3.22. Soldurii is a Celtic loanword which some classicists have, unhelpfully, translated as 'vassals of a chieftain': see C.B. Krebs, A style of choice, in: The Cambridge companion to the writings of Julius Caesar, eds. L. Grillo and C.B. Krebs, Cambridge 2018, p.110-130, at 126. One nineteenth century translation actually describes them as "persons lying under feudal obligations" (W.A. McDevitte and W.S. Bohn, Caesar's commentaries on the Gallic and Civil Wars, New York 1870, p.78, n.1). By contrast, the institutional writer Erskine, possessed of a more nuanced understanding of feudal law, was able to say decisively that the relationship between soldurii and their chiefs "was in no respect feudal" and proceeded "not from feudal obligations, or oaths of fidelity, but from the affection which all of the same tribe have to their head or chieftain" (J. Erskine, An institute of the law of Scotland, 2.3.2 [= vol.1, p. 298 in the 1871 Edinburgh two-volume edition]).

156 Kelley, The rise of legal history (supra, n.4), p.189-190

157 Hotman, Disputatio de jure feudali, 14: Quod vero Franc. Connanus vir doctissimus disputat feudorum morem a Gallis ad Germanos, Hispanos, Italos, et alios Europae populos venisse.

$158 \mathrm{He}$ does, however, cite Connan approvingly and by name elsewhere; e.g., JF 1.12.12. 
contrast, in the previous section, Craig was dealing with the much more popular and much more important Romanist theory which demanded explication at greater length. In the next section, Craig mentions the idea of a Spanish origin, based upon material found in Plutarch and Valerius Maximus. ${ }^{159}$ This too is discussed by Hotman and the same classical sources are cited. ${ }^{160}$ Given that Craig's Greek was not ideal and that Valerius is a relatively obscure author, it is probably not uncharitable if we assume that he would been unaware of the contents of either text if not for Hotman.

From Spain, Craig progresses to Germany and the idea that the origins of feudal tenure can be found in Tacitus' Germania. ${ }^{161}$ The treatment here is limited, because, as he says, this is material which was examined earlier in much greater detail. Were one to read this section in isolation, it would not be immediately clear that this theory is one to which Craig was deeply attached, indeed, one which he considered self-evidently true. This title as a whole serves as a basic review of feudal thought; its broad didactic function is to introduce a predominantly Scottish readership to the trends of humanist thinking on the origins of feudal law and tenure. Hence Craig feels no need to labour points or go into great detail. From Germany, Craig surprisingly proceeds to Greece where it is claimed that the feudal law originated with a decree of the Byzantine emperor Constantine VII Porphyrogenitus who ruled from 912 until his death in 959 . Given that, by the time Craig was writing, the whole of Greece was under the rule of the Ottoman Turks, it seems peculiar to suppose that the origins of feudal tenure were a matter of much importance to anyone in that country. Moreover, the Byzantines never developed feudalism in the Western European sense, having, instead, a superficially similar system called pronoia. ${ }^{162}$ Craig's source on this cannot be Hotman, since

159 JF 1.5.5, citing Plutarch, Sertorius, 14 and Valerius Maximus, Dicta memorabilia, 2.6.11.

160 Hotman, Disputatio de jure feudali (supra, n.30), 15

$161 J F 1.5 .6$

162 Regarding which, see W. Treadgold, A history of the Byzantine state and society, Stanford, 1997, p.680-681. Marxist and historical materialist scholars do, in fact, argue that Byzantium was a feudal society because it was "dominated by feudal relations of production" (J. Haldon, The feudalism debate once more: the case of 
his work does not mention Greece or the Greeks in connexion with feudal law or tenure. It seems most likely that he was drawing upon Cujas whose commentary on the Libri feudorum describes a novella or constitution of Constantine Porphyrogenitus which mentions the holding of estates (praedia militaria) in return for military service (onus militiae). ${ }^{163}$ The fact that Craig could switch so fluidly from Hotman's work to that of Cujas shows something about the availability of humanist texts for a Scottish lawyer in this period; ${ }^{164}$ therefore, it reveals something about the breadth of Craig's reading and indicates, again, that his treatment of feudal origins should be seen as both corollary and response to Continental humanist jurisprudence and historiography. ${ }^{165}$

In the next section, Craig delivers his response to the various theories he has just summarised. Showing once more his keen awareness of anachronism and periodisation, he tells us that none of these theories can fully explain the origins of feudal tenure because, prior to the barbarian invasions of the Roman empire, no instances of feudal terminology or practice are to be found; as Craig sees it, feudal tenure requires a specific form of language to describe it and a specific form of custom to govern it, so it follows that the earliest point at which feudal tenure could have existed is the point at which feudal concepts like fealty, homage, investiture and duplex dominium can be shown to have existed. ${ }^{166}$ It is also in this section that Craig explains why so many different theories for the origin of feudal tenure and law exist; from his Scottish perspective, the fault lies with misplaced patriotism. Learned men invent arguments that flatter their own countries. This is a short comment, but reflects some of the issues Craig wrestled with as a British unionist. In writing this section, he was

Byzantium, Journal of Peasant Studies 17 (1989), p.5-40, at 16), by which is meant a system where an elite class dominated the productive class and absorbed any surplus production.

163 Cujas, De feudis libri quinque, Montréal, 1567, p.10 (but p.8 of the 1588 Cologne edition).

164 In the sixteenth century, law books were often brought back from the Continent by students who had completed their studies and these were often traded and loaned between legal practitioners; see J. Finlay, Men of law in pre-reformation Scotland, East Linton 2000, p.88.

165 Cf. J. Irvine Smith, The transition to the modern law 1532-1660, part I: the general development of Scots law, in An introduction to scottish legal history [=Stair Society, vol. 20], Edinburgh 1958, p.25-43, at 31 $166 J F 1.5 .8$ 
presumably thinking about some of the same issues that he addressed in his treatise $D e$ hominio ('On homage') where he used arguments about feudal chronology to disprove the old English canard that Scotland was a liege feu of England. ${ }^{167}$ The sole English translation of the De hominio, by George Ridpath in 1695, was titled Scotland's Sovereignty Asserted and, while one can construe the work in that way, from Craig's point of view, it was the English historians who were asserting something; he was merely correcting them.

Regardless, one can see that he was deeply conscious that patriotic bias could lead to the misuse of history, whether through deliberate distortion or simple partiality.

The final section is a refutation of all the theories laid out in the rest of the title. ${ }^{168} \mathrm{~A}$ Roman origin for feudal tenure is discounted because, as Craig sees it, clientage in the ancient world has none of the distinct characteristics that he associates with feudal practice: clients had no obligation of military service; patrons had no obligation to provide material benefits for their clients and nor did they exercise jurisdiction; and there was no oath of fealty. Whatever clientage may have been, it was not feudal. Nor can the Roman policy of giving land to veterans be construed as feudal, because veterans were men who had already completed their service whereas feus were given to young men whose military service lay ahead of them. Further, the land received by Roman veterans had been taken from conquered foes. The feudal practice involved vassals receiving land that already belonged to their lord or king. The absence of oaths of fealty is again a decisive argument: since Roman veterans swore no oaths, as demanded by the feudal law, their tenure cannot have been feudal. The constitution of Constantine VII is easily brushed aside on grounds that it dates to the year 912 and is therefore too recent to mark the beginning of feudal law or tenure. Indeed, Craig notes that it is possible that the Greeks could have appropriated their own feudal practice from the

\footnotetext{
167 See Dodd, Historical introduction (supra, n.85), p.xxiii-xiv and C. Kidd, Subverting Scotland's past: Scottish Whig historians and the creation of an Anglo-British identity, Cambridge, 1993, p.44. $168 J F 1.5 .9$
} 
laws of Charlemagne or his grandson Lothair. On the basis of all of this, he asserts, the only plausible source for feudal law and tenure in Europe is ancient Germany, as described by Tacitus, whence, following the invasion of the Roman empire, feudal customs spread to the whole of Christendom. Perhaps the single most interesting aspect of this section is that Craig is indirectly providing a kind of checklist of the features he considers intrinsically feudal. In effect, by telling us that an origin narrative must be incorrect because it lacks this or that characteristic, he is revealing the features that he understood as inherent to feudal tenure and law.

\section{Conclusion}

In examining Thomas Craig's treatment of the origins of feudal law and tenure, we have seen throughout that he was merely one link in a long of chain of feudal lawyers stretching all the way back to Baldus. His work drew upon a vast body of literature, classical, mediaeval and modern. He not only employed primary sources, such as Tacitus, but relied upon humanistic interpretative literature, such as that of Hotman and Bodin. One may wonder why this matters so much, given that anyone who has actually read the Jus feudale will have seen a battery of references, citations and, on more than a few occasions, recommendations for further reading. To say that Craig was merely one writer among many could be a statement of the obvious. Yet outside the fields of law and legal history. Craig has been sometimes presented, usually in negative terms, as the inventor or originator of various aspects of feudal law and theory. So it is that the mediaeval historian Elizabeth Brown singled Craig out for harsh criticism and blamed him for creating the idea of a pyramidal feudal system and then communicating it to future generations of historians through the Jus feudale. ${ }^{169}$ Elsewhere Craig has been described as an antiquarian at the Stuart court who 
discovered the feudal law and introduced it to James VI, thereby informing the king's understanding of monarchy. ${ }^{170}$ Other examples abound and they are all fundamentally in error because they fail to appreciate the literary and juristic contexts within which Craig was writing.

Not only was the Jus feudale dependent upon Continental scholarship, it was also an explicit attempt to bring feudal theory from the law schools of France to the law courts of Scotland. The treatise was in part intended to forge an intellectual link between the European mainstream, represented especially by France, and a peripheral kingdom that was neither wealthy nor politically important. What makes Craig unique is that he was the first Scot and Briton to apply himself to the question of the feudal law's place within the wider framework of Scots law; and therefore to the question of Scots law's place within the wider framework of the ius commune. Craig was the first to articulate and explore the notion that both Scots and English law were best understood within a European context and that, therefore, European juristic theory was a useful key to unlock the interpretation of British law. Beyond that, Craig was also the first British lawyer to employ the critical methodologies of Continental legal humanism in a comprehensive fashion, the first to use those methodologies in the production of a major treatise, and, indeed, the first Scot to create a comprehensive study of law. While Scottish intellectuals of the sixteenth century were avid consumers of the European humanist product, they were not, with a few notable exceptions like Buchanan, major contributors to the common pool of European learning. Craig's Jus feudale represents an attempt to change that, at least in the field of law.

Qu'est-ce que la féodalité? (supra, n.70) alongside Craig's account. The similarities between Craig and the modern mediaevalists against whom Brown railed may explain her assumption that the Jus feudale was, in some way, the original source of the construct of feudalism and that Craig bore final responsibility for misleading modern mediaeval historians into believing that feudal social relations were a pyramidal structure uniformly present across every part of Europe.

170 J.E. Berg, Gorboduc as a tragic discovery of "feudalism”, Studies in English Literature 1500-1900 40 (2000), p.199-226, at 201-2 
This self-conscious commitment to the humanist historiographical method is, by itself, enough to explain Craig's focus on the origins not only of the feudal law but of law and society generally. The humanist writers by whom Craig was so deeply influenced considered origins to be a central component in the writing and interpretation of history and so, in writing a humanistic text, Craig could not have done other than follow the epistemological and literary structures that they laid down. There is, though, another reason, specific to Craig, for exploring law's origins. As Prof. Ford has shown, the concept of translatio studii underlay Thomas Craig's understanding of and approach to law and history. ${ }^{171}$ Law had its divinelyinspired origin in Biblical Israel and from there had passed, via ancient Egypt, to Greece and Rome and then to the law schools of early modern France whence not only law, but also the interpretative or heuristic mechanisms of humanistic legal thought, were brought to Scotland by jurists like Craig. ${ }^{172}$ The study of feudal origins served several different but complementary functions. It provided the practising lawyer with historical precedent. It showed the way that this law, which straddled the line between ius proprium and ius commune, had developed over time until crystallising into specific local expressions. ${ }^{173}$ It connected Scots law and Scots lawyers with European feudal legal theory. Ultimately, it served to establish an ongoing institutional basis for future historico-legal thought in Scotland by uniting history and law beneath the humanist method.

171 Ford, Law and opinion (supra, n.9), p.50-51

172 Ibid., p.222-223

173 Ibid. p.494; Dodd, Historical introduction (supra, n.85), p.xxx-xxxi 